\title{
Morfología macroscópica de alteración de la piedra del conjunto catedralicio de Granada/España
}

\section{Macroscopical morphology of deterioration of the stone used in the cathedral whole of Granada/Spain}

\author{
ALCALDE, M. $\left({ }^{\star}\right)$; MARTIN, L.(**); BELLO, M. A. $\left({ }^{\star \star}\right)$; MARTIN, A. $\left({ }^{\star \star}\right)$ \\ UNIVERSIDAD DE SEVILLA \\ (*) Dpto. de Ingeniería Quimica y Ambiental \\ $\left(^{\star *}\right)$ Dpto. de Quimica Analítica
}

Fecha de recepción: 11-Vl-92.

\section{RESUMEN}

Los principales factores de alteración que actúan en el conjunto catedralicio de Granada son, uno natural de origen térmico, dadas las bajas temperaturas que se alcanzan en invierno, y las grandes oscilaciones térmicas que se registran durante gran parte del año, y los de origen antropogénico, fundamentalmente los de mal uso de elementos de sujeción metálicos oxidables y los de contaminación atmosférica debida a productos de combustión. De esta forma, los mecanismos de alteración primordiales son los de heladicidad por la expansión producida por la congelación del agua retenida en los poros y microgrietas, sobre todo en los elementos arquitectónicos de mayor superficie de exposición y en su orientación umbría. Los indicadores a que ello conduce son las fisuras y fragmentaciones. Así, muchos elementos de piedra de Santa Pudia de la crestería de la Capilla Real se han perdido y los que quedan se encuentran muy degradados. La piedra de Sierra Elvira de las cornisas, más compacta, también se ve afectada por este mecanismo, iniciado por las microgrietas provocadas por dilataciones diferenciales debidas a oscilaciones térmicas, que facilitaron el acceso al agua. La expansión de hierros al oxidarse ha provocado la fracturación y fisuración de gran número de elementos ornamentales como bolas, pináculos, etc, que han obligado al desmontaje de muchos de ellos por el riesgo de caída, sobre todo en las terrazas superiores del monumento.

Los mecanismos de disolución, ciclos de cristalización y acción química han conducido a la pérdida abundante de materia, tanto en forma de arenizaciones, sobre todo en las zonas de mayor humedad, como de formación de huecos (picados, alveolizaciones, estriados), en aquellas zonas más expuesta al viento. Esto afecta de forma generalizada a las zonas bajas en todo el perímetro del edificio, excepto en gran parte de la fachada principal, así como en todos los antepechos y en las superficies situadas debajo de las cornisas. Estas arenizaciones se ven favorecidas cuando existen placas biológicas o depósitos de inquemados, siendo estos últimos de mayor abundancia en las superficies más cercanas a la Gran Vía y en su orientación hacia ésta. Por último, y sobre todo por su repercusión estética, es necesario mencionar los abundantes depósitos de guano de palomino, cuya mayor presencia se da en la fachada principal.

\section{$S U M M A R Y$}

The main factors of deterioration that affect the Cathedral Whole of Granada are one of natural thermic origin due to the low temperatures during the winters and the higher thermic oscillations and those of anthropogenical origin: fundamentally the oxidation of metallic elements and atmospheric pollution due to burnt products. For this reason, the more important deterioration mechanisms are the freezing ones due to the expansion produced in the water retained inside the pores and microcracks, fundamentally in the architectonic elements with high expositional surface and in their shady orientation; the main indicators produced are fissuring and spalling. In this way, a lot of elements of Santa Pudia stone located in the Royal Chapel crenellations have disappeared and the rest are very deteriorated. The more compact Sierra Elvira stone used on the upper zone of the cornices has also been affected by the freezing mechanism, which starts with the microcracks produced by differential dilatations due to the thermic oscillations which made the water access easy. The iron corrosion and later expansion of the oxidation products has provoked the cracking and fissuring of many ornamental elements like balls, pinnacles, etc, and this situation has obliged their dismantling on the upper zones due to the danger to the public.

The mechanisms of dissolution, crystallization cycles and chemical action have led to abundant material loosening in the form of grain disgregation overcoats on the higher humidity zones, and formation of hollows (pitting, alveolar erosion, striations) in the zones more exposed to the winds. This situation is generalized in the lower zones of the monument, except on the main façade, and in the parapets and lower zones of the cornices. The grain disgregations are more important when biological crusts or unburned deposits exist, the latter being of major abundance on the surfaces near the Gran Via and in its orientation. It is necessary to mention the pigeon dung deposits, very important in the main façade, with greater stetical repercussion. 


\section{INTRODUCCIÓN}

El Conjunto Catedralicio está constituido por la Catedral de la Encarnación, Iglesia Parroquial del Sagrario, Capilla Real, Lonja, Colegio de San Fernando y viviendas que forman una unidad urbanística, una manzana completa entre las calles Pasaje de Siloé, Cárcel, plazas de las Pasiegas y de Alonso Cano y calle Oficios. La Catedral de Granada está situada en el centro de la antigua medina árabe y el Sagrario de la Catedral ocupa el lugar en el que estuvo emplazada la Mezquita mayor de la ciudad.

Aunque en un principio la antigua mezquita fue acondicionada para el culto cristiano, dado que el templo resultaba muy pequeño, se decide en 1505 la construcción de la Catedral y de la Capilla Real, que sería sepultura de los Reyes Católicos; no obstante, la construcción de la Catedral no se inicia hasta 1518 , fecha esta en la que las obras de la Capilla Real estaban prácticamente concluidas. La construcción de la Lonja se inicia en estas mismas fechas, quedando finalizada 4 años más tarde. En lo que respecta a la iglesia del Sagrario, sus obras comienzan en 1704, previa demolición de los restos que quedaban de la antigua mezquita. Las obras de la Catedral y el Sagrario quedan definitivamente concluidas a finales del siglo XVIII, al igual que una remodelación de la fachada de la Capilla Real.

El Conjunto Catedralicio de Granada ha sufrido desde el comienzo de su construcción numerosas vicisitudes que de una $u$ otra forma obligaron a paralizaciones de las obras, como la insurrección de los moriscos en 1526 o a los diversos períodos de falta de recursos económicos, o a reconstrucciones necesarias tras algunos derrumbamientos.

\section{ENTORNO AMBIENTAL}

El Conjunto Catedralicio de Granada se encuentra situado en el centro urbano de la ciudad, rodeado de calles de escaso dimensionamiento, y a pocos metros de vías de muy alta densidad de tráfico. Sólo la Fachada Principal de la Catedral, abierta a la Plaza de las Pasiegas (peatonal), puede ser admirada desde una perspectiva adecuada. La dirección longitudinal de la Catedral es de noreste a suroeste, estando situada la Fachada Principal a los pies del templo.

\subsection{Clima}

La ciudad de Granada, a una altitud de $664 \mathrm{~m}$, está situada en la denominada Iberia Parda (clima mediterráneo), en la región continental, subregión continental extremada, meseta sur. De las medidas efectuadas por el Observatorio

\section{INTRODUCTION}

The Cathedral Whole is constituted by the Cathedral of the Encarnación, the Sagrario Parochial Church, Royal Chapel, Lonja, San Fernando College and some houses which are an urbanistic unity between the Pasaje de Siloé, Carcel and Oficios Streets and the Pasiegas and Alonso Cano Squares. The Cathedral of Granada is located in the center of the ancient arabian mosque and the Sagrario is found where the Mayor Mosque of the city was located.

Originally, the ancient mosque was conditioned for the christian worship but the temple was very little and for this reason in 1505 the decision of the construction of the Cathedral and of the Royal Chapel was taken, which should be the tomb of the Catholic Monarchs; however, the construction of the Cathedral was not started until 1518, when the building of the Royal Chapel was practically concluded. The construction of the Lonja started at this time and was concluded four years later. The construction of the Sagrario started in 1704, after demolition of the remains of the ancient mosque. Work on the Cathedral and Sagrario finished at the end of the 18th century, and at this time a remodelling of the façade of the Royal Chapel was concluded.

The Cathedral Whole of Granada has suffered numerous accidents, such as the Moorish revolt in 1527 , the diverse periods with less economic resources, or reconstructions after some plunges which, to a greater or lesser extent, forced some paralysis of the works.

\section{ENVIROMENTAL SURROUNDINGS}

The Cathedral Whole of Granada is located in the city centre, flanked by narrow streets, and not far from the monument there are very important traffic ways. Only the main façade of the Cathedral, open to the Pasiegas Square (pedestrianized zone) can be admired from an adequate perspective. The Cathedral linear direction is from Nordeast to Southwest while its main façade Southwest.

\subsection{Climate}

The city of Granada, $664 m$ above sea level, is located in the Iberia Parda (mediterranean climate), continental region, extreme continental subregion, Southern Meseta. From the data obtained from the meteorological observatory of 
Meteorológico de Granada Ba-Armilla durante los años 1930 a 1990, así como de otros datos del Instiuto Nacional de Meteorología $(1,2)$ pueden extraerse como conclusiones más importantes las siguientes:

De acuerdo con las características de la zona climática en que se encuentra situada Granada, los inviernos son muy fríos y los veranos bastante calurosos. El mes más cálido es julio con una media en sus temperaturas máximas de $34^{\circ} \mathrm{C}, y$ el más frío enero con una media en sus temperaturas mínimas de tan solo $1,5^{\circ} \mathrm{C}$, siendo la media anual de temperatura de $15,1^{\circ} \mathrm{C}$. Se debe tener en cuenta la influencia de heladas puesto que el n.- medio de días al año con temperatura menor de $0^{\circ} \mathrm{C}$ es del orden de 30 , concentrándose éstos en los meses de diciembre a febrero. Las oscilaciones térmicas tienen una media a lo largo del año de $14^{\circ} \mathrm{C}$, siendo máximas en los meses de junio a agosto con $18^{\circ} \mathrm{C}$; no obstante, en observaciones realizadas por los autores, se han podido medir oscilaciones diarias cercanas a los $30^{\circ} \mathrm{C}$.

La humedad relativa media anual es del $68 \%$, alcanzando sus valores máximos en los meses de noviembre a febrero, con una media diaria del 76 $\%$, y valores punta a las $7 \mathrm{~h}$. entre el $85-90 \%$, que descienden hasta un $60-65 \%$ a las $13 \mathrm{~h}$. El mes más seco es julio $(38 \%)$ con valores a las 7 h. del $60-65 \%$, y a las 13 h. del $30 \%$.

La precipitación media anual es de $390 \mathrm{l} / \mathrm{m}^{2}$, repartidos en una media de 90 días de lluvia al año. Los meses con media pluviométrica más alta van desde octubre a abril $\left(40-54 \mathrm{l} / \mathrm{m}^{2}\right)$, siendo julio $y$ agosto los menos lluviosos $\left(2-6 \mathrm{l} / \mathrm{m}^{2}\right)$. El número medio de días al año de nevadas intensas es de 1.5 , con valores medios máximos en los meses de diciembre a febrero.

Durante todo el año los vientos predominantes son del S. aunque algo más variables en verano. La velocidad media anual es de $10 \mathrm{~km} / \mathrm{h}$, con una frecuencia del $54 \%$ para aquellos que alcanzan velocidades superiores a $6 \mathrm{~km} / \mathrm{h}$ y $\tan$ solo un $2 \%$ de los mismos alcanzan velocidades superiores a los $50 \mathrm{~km} / \mathrm{h}$ (durante el verano y de dirección $\mathrm{SO}$ ).

\subsection{Contaminación}

Los focos emisores de productos contaminantes del aire más importantes son los vehículos a motor y en invierno hay una contribución importante de las calefacciones. Como ya ha sido comentado, cercanas al Conjunto Catedralicio discurren dos vías de muy alta densidad de tráfico y, debido al trazado urbanístico de la zona, los contaminantes producidos se dispersan con dificultad; la influencia del tráfico queda demostrada a través de registros diarios de varios
Granada Ba-Armilla taken between 1930 and 1990 , and other data taken by the National Institute of Meteorology [1, 2], the most important conclusions we can extract are:

According to the climatic zone where Granada is located, the winters are very cold and the summers are quite warm. July is the hottest month with an average maximum temperature of $34^{\circ} \mathrm{C}$, and January is the coldest month with an average daily minimum temperature of only $1.5^{\circ} \mathrm{C}$, the average yearly temperature only $15.1^{\circ} \mathrm{C}$ being. The influence of frosts must be considered as the average number of days/year on which the minimum temperature is less than $0^{\circ} \mathrm{C}$ is approximately 30 , which are concentrated between December to February. The daily thermic oscillation have an average during the year of $14^{\circ} \mathrm{C}$, the maximum being during June to August with an average of $18^{\circ} \mathrm{C}$; however, some data obtained for the authors indicate that thermic oscillations of $30^{\circ} \mathrm{C}$ can be registered.

The average yearly relative humidity is of $68 \%$, with maximum values during November to February, with a daily average of $76 \%$ and valued at $7 \mathrm{~h}$ of $85-90 \%$, which go down to $60-65 \%$ at 13 h July with $38 \%$ has the minimum daily average relative humidity, with values at $7 h$ and $13 \mathrm{~h}$ of $60-65$ and $30 \%$, respectively.

The yearly average rainfall is $390 \mathrm{l} / \mathrm{m}^{2}$, spread over an average days of rainfall of 90 . The months with the highest average rainfall are October to April (40-54 $\left.1 / \mathrm{m}^{2}\right)$ July and August being the months with lower rainfall $\left(2-6 \mathrm{l} / \mathrm{m}^{2}\right)$. The yearly average number of days with intense snowfall is 1.5 , with maximum average values during December to February.

The $S$ wind is the dominating direction during the year, with some variability in the direction during the summer. The average yearly speed is 10 $\mathrm{Km} / \mathrm{h}$, with a frequency of $54 \%$ for those whose speeds are higher than $6 \mathrm{Km} / \mathrm{h}$ and over only the $2 \%$ of the winds have speeds higher than 50 $\mathrm{Km} / \mathrm{h}$ (in the summer and with SW direction).

\subsection{Pollution}

The more important emitting sources of atmospheric pollution are the internal combustion engines and, during the winter, there is an important contribution from heating. Near the Cathedral Whole two high traffic density ways exist, and due to the urban desing, the pollutants produced do not disperse easily; the influence of traffic has been demonstrated by means of daily registers of some parameters in the surrounding of the building, maximum being the $\mathrm{CO}, \mathrm{SO}_{2}$ and 
parámetros en las cercanías del Conjunto, siendo máximos los valores de $\mathrm{CO}, \mathrm{SO}_{2}$ y $\mathrm{NO}_{\mathrm{x}}$ de 8 a 11 horas, que se corresponden con el período de mayor intensidad de tráfico rodado; el aumento que se produce durante las primeras horas de la noche puede tener su explicación en la existencia de fenómenos de inversión térmica.

Se dispone de datos correspondientes a los años 1990 y 1991 , con medias diarias de $14-60 \mu \mathrm{g} / \mathrm{m}^{3}$ $\mathrm{SO}_{2}, 5-10 \mu \mathrm{g} / \mathrm{m}^{3}$ de CO, $150-300 \mu \mathrm{g} / \mathrm{m}^{3}$ de $\mathrm{NO}_{x} \mathrm{y}$ $39-470 \mu \mathrm{g} / \mathrm{m}^{3}$ de particulas en suspensión; se han llegado a detectar valores máximos diarios de 500 $\mu \mathrm{g} / \mathrm{m}^{3}$ de $\mathrm{SO}_{2}, 30 \mu \mathrm{g} / \mathrm{m}^{3}$ de $\mathrm{CO}, 900 \mu \mathrm{g} / \mathrm{m}^{3}$ de $\mathrm{NO}_{x}$ y $800 \mu \mathrm{g} / \mathrm{m}^{3}$ de partículas en suspensión.

Se han realizado algunas medidas en el propio Conjunto, encontrándose unos valores medios de humos de $18,4 \mu \mathrm{g} / \mathrm{m}^{3}$ en la Capilla Real, muy influenciada por una de las grandes avenidas antes comentadas, y $9,9 \mu \mathrm{g} / \mathrm{m}^{3}$ en la fachada principal, más alejada de los focos emisores. En cuanto a las partículas sedimentables, se han registrado valores medios del orden de 100 $\mathrm{mg} / \mathrm{m}^{2}$ día, que no son excesivamente altos.

\subsection{Subsuelo}

El Conjunto se encuentra asentado en las cercanías del antiguo cauce del río Darro, existiendo una elevada humedad en el subsuelo; de hecho existe un antiguo pozo adosado a la fachada de la Capilla Real.

La cimentación del edificio llega hasta un sustrato de tipo granular constituido por arcillas, y se realizó con mortero de cal que se encuentra en la actualidad poco aglomerado.

Se ha de mencionar aquí, que Granada se encuentra en una zona de elevada actividad sísmica, en la que se han dejado sentir varios episodios sísmicos importantes desde el inicio de la construcción del Conjunto Catedralicio; sólo en los dos últimos siglos se han señalado cuatro terremotos de intensidades VII a X (escala MKS) con epicentros muy próximos a la ciudad. Terremotos menores son muy frecuentes e, indudablemente, han contribuido en cierta medida al deterioro del monumento.

\section{MATERIALES PÉTREOS}

En primer lugar, y mayoritariamente en todo el edificio, se ha empleado una caliza porosa y blanda de color amarillento procedente de las canteras de Santa Pudia, en la zona del Cortijo de Santa Pudia, en el término municipal de Escuzar, a $23 \mathrm{~km}$ al suroeste de Granada. Las canteras que más debieron utilizarse en el pasado se encuentran en las proximidades del Cortijo de La Escribana (4 km al sur de Escúzar)
NO values between 8 and $11 \mathrm{~h}$, which correspond to the major traffic intensity period; during the first night hours the increase on the pollution values can be explained in basis to thermic inversion phenomena.

The data corresponding to 1990 and 1991 reveal average daily values of $14-60 \mu \mathrm{g} / \mathrm{m}^{3}$ of $\mathrm{SO}_{2}, 5-10$ $\mu \mathrm{g} / \mathrm{m}^{3}$ of $\mathrm{CO}, 150-300 \mu \mathrm{g} / \mathrm{m}^{3}$ of $\mathrm{NO}_{x}$ and $39-470$ $\mu \mathrm{g} / \mathrm{m}^{3}$ of suspended particles; daily maximum of $500 \mu \mathrm{g} / \mathrm{m}^{3}$ of $\mathrm{SO}_{2}, 30 \mu \mathrm{g} / \mathrm{m}^{3}$ of $\mathrm{CO}, 900 \mu \mathrm{g} / \mathrm{m}^{3}$ of $N O_{x}$ and $800 \mu \mathrm{g} / \mathrm{m}^{3}$ of suspended particles have been registered.

On the Cathedral Whole average daily smog values of $18.4 \mu \mathrm{g} / \mathrm{m}^{3}$ and $9.9 \mu \mathrm{g} / \mathrm{m}^{3}$ on the Royal Chapel and main Façade, respectively, have been registered; as has been previously mentioned, the first zone is more influenced by the high traffic ways. In respect to the sedimentable particles, average values of $100 \mathrm{mg} / \mathrm{m}^{2}$ day have been registered which are not higher.

\subsection{Subsoil}

The Cathedral Whole is located on the nearness of the ancient Darro's riverbed, which provokes high subsoil dampness, in fact an ancient well leaned sth against the Royal Chapel façade exists.

The building foundations reach a granular substrate constituted by clays, and they have been made with lime mortar which nowadays presents low agglomeration.

Granada is located in an high seismicity zone, where some important earthquakes have been produced since the start of the Cathedral Whole building; just in the two last centuries four earthquakes of VII to $X$ intensity (MKS scale) with epicenters very near to the city have been registered. Lower earthquakes are very frequent and they have contributed to the monument deterioration.

\section{STONY MATERIALS}

In the first place, and fundamentally in all the building porous and soft limestone of yellowish colour from the Santa Pudia quarries (Cortijo de Santa Pudia zone) located in Escuzar, $23 \mathrm{Km} \mathrm{SW}$ of Granada, has been used. The main quarries used are located near the "Cortijo de la Escribana" (4 Km S of Escuzar) and in the "Parideras de las canteras", on the northern side of the Serrezuela hill ( $3 \mathrm{Km} S$ of Escuzar), From 
y en las llamadas "Parideras de las Canteras", en la vertiente septentrional del Cerro de la Serrezuela ( $3 \mathrm{~km}$ al sur de Escúzar). Desde el punto de vista geológico (3) los materiales corresponden a sedimentos terciarios de edad Miocena (Tortoniense medio-Messiniense) que forman parte del borde meridional de Granada.

La piedra de Santa Pudia puede presentarse en diferentes grados de compacidad, por lo que distinguiremos entre una variedad compacta (SPC) y una menos compacta (SP); ambos litotipos han sido empleados en el Conjunto Catedralicio. Puede definirse como una caliza bioesparítica de color amarillento, de textura heterogranuda, acusadamente inequigranular. Su grado de cementación es muy escaso y presenta una elevada porosidad, con frecuentes interconexiones entre los poros (variedad no compacta). Los términos litológicos superiores del conjunto explotado tienen una mayor cementación, lo que le proporciona una más elevada compacidad (variedad compacta).

El segundo litotipo, utilizado principalmente en el Sagrario, es una caliza compacta y dura de color gris procedente de las canteras de Sierra Elvira, que se encuentran en el término municipal de Atarfe, en la provincia de Granada. Dichas canteras, en número superior a treinta, siguen actualmente en explotación utilizándose esta caliza cor roca de construcción y ornamental. En la vertiente sureste de la Sierra, que es donde existen los mejores cortes estratigráficos, afloran unas calizas grises con nódulos de silex. Son calizas bien estratificadas en bancos de más de $20 \mathrm{~cm}$, alternantes con otros finos, algo pizarrosos. Las reservas se concentran en este paquete, actualmente explotado, de calizas espáticas crinoides, de estratificación masiva, superior al metro de potencia por estrato.

La piedra de Sierra Elvira es una caliza micrítica de textura equigranuda alotriomorfa a heterogranuda inequigranular, en ciertos casos bandeada. Se presentan dos variedades claramente distinguibles por su coloración y que en sus características petrográficas son bastantes similares con la salvedad del tamaño de grano: más fino en la variedad rojiza que en la gris, esta última podría definirse como una biopelsparita (encrinita) con cemento esparítico y la variedad rojiza como una biomicrita de cemento micrítico, localmente microesparítico; la cementación en ambos casos es elevada lo que le confiere a la piedra una porosidad prácticamente nula.

En la tabla 1 puede observarse la composición química media de los materiales de Santa Pudia y Sierra Elvira, y en la tabla 2, los correspondientes valores de porosidad abierta al agua y densidad. the geological point of view (3) the materials correspond to tertiary sediments from Miocene era (Tortoniense medium-Messieniense) which constitute the southern side of Granada.

Santa Pudia stone can show different compacity degrees, for this reason we distinguish between the compact variety (SPC) and the less compact one (SP); both lithotypes have been employed in the Cathedral Whole it can be defined as a biosparitic limestone of yellowish colour, heterograined texture very inequigranular. Its cementation degree is very scarce and presents frequent pore interconnection (non-compact variety). The upper lithological terms have a superior cementation, which implies major compacity (compact variety).

The second stone type, principally used on the Sagrario, is a very compact limestone of grey colour from Sierra Elvira quarries (Atarfe, Granada). These quarries, more than 30 , are in explotation nowadays and the stone is used for building and ornamental purposes. In the SW side of the sierra, where the best materials exist, grey limestones with silex nodules crop out. They are well stratified limestones which appear as $20 \mathrm{~cm}$ benchs, and alternate which other thinner ones, rather slaty. The reserves are concentrated in this packet, in explotation nowadays, constituted by spatic crinoidal limestones of massive stratification, above $1 \mathrm{~m}$ power by stratum.

The Sierra Elvira stone is a micritic limestone of alotrimorfe equigrained to inequigranular heterograined texture, with striping in certain cases. Two colour varieties can be distinguished, their petrographical characteristics are very similar, we must mentioned that the reddish variety has a smaller grain that the grey one; this last stone type should be defined as biopelsparite (encrinite) with sparitic cement and the reddish variety as biomicrite of micritic cement, microsparitic in some zones; the cementation in both varieties is very high which implies a much lower porosity.

Table 1 shows the medium chemical composition for the Santa Pudia and Sierra Elvira materials, table 2 shows the corresponding porosity and density values. 
TABLA 1 TABLE 1

Composición macroquímica $(\% \mathrm{p} / \mathrm{p})$ de los materiales de Santa Pudia y Sierra Elvira (Chemical major composition $\% \mathrm{w} / \mathrm{w}$ ) of the Santa Pudia and Sierra Elvira materials)

\begin{tabular}{|c|c|c|c|c|c|c|c|c|c|c|c|}
\hline \multicolumn{2}{|c|}{$\begin{array}{l}\text { Muestra } \\
\text { (Sample) }\end{array}$} & $\begin{array}{l}\text { Pérdida } \\
\text { (loss on }\end{array}$ & $\mathrm{SiO}_{2}$ & $\mathrm{Al}_{2} \mathrm{O}_{3}$ & $\mathrm{Fe}_{2} \mathrm{O}_{3}$ & $\mathrm{CaO}$ & MgO & $\mathrm{Na}_{2} \mathrm{O}$ & $\mathrm{K}_{2} \mathrm{O}$ & $\mathrm{SO}_{3}$ & Total \\
\hline \multirow{2}{*}{ SPC } & $\begin{array}{l}\text { Media } \\
\text { (median) }\end{array}$ & 42,23 & 2,39 & 0,38 & 0,36 & 53,19 & 0,41 & 0,77 & 0,18 & 0,26 & 100,17 \\
\hline & $\begin{array}{l}\text { Intervalo } \\
\text { (interval) }\end{array}$ & $41,8-42,8$ & $2,1-3,1$ & $0,3-0,5$ & $0,3-0,4$ & $53,0-53,3$ & $0,3-0,5$ & $0,7-0,9$ & $0,1-0,3$ & $0,2-0,3$ & \\
\hline \multirow{2}{*}{ SP } & $\begin{array}{l}\text { Media } \\
\text { (median) }\end{array}$ & 43,31 & 1,26 & 0,15 & 0,26 & 53,90 & 0,35 & 0,75 & 0,10 & 0,28 & 100,36 \\
\hline & $\begin{array}{l}\text { Intervalo } \\
\text { (interval) }\end{array}$ & $43,0-43,6$ & $0,5-1,9$ & $0,1-0,2$ & $0,2-0,4$ & $53,1-54,6$ & $0,3-0,4$ & $0,6-0,9$ & $0,05-0,2$ & $0,2-0,4$ & \\
\hline \multirow{2}{*}{ SE } & $\begin{array}{l}\text { Media } \\
\text { (median) }\end{array}$ & 43,52 & 0,47 & 0,10 & 0,19 & 53,46 & 1,18 & 0,50 & 0,18 & 0,42 & 100,02 \\
\hline & $\begin{array}{l}\text { Intervalo } \\
\text { (interval) }\end{array}$ & $43,0-43,9$ & $0,2-0,9$ & $0,05-0,2$ & $0,5-0,4$ & $52,9-54,1$ & $0,8-1,7$ & $0,3-0,7$ & $0,1-0,3$ & $0,2-0,8$ & \\
\hline
\end{tabular}

TABLA 2 TABLE 2

Porosidad y densidad de los materiales de Santa Pudia y Sierra Elvira (Porosity and density of the Santa Pudia and Sierra Elvira materials)

\begin{tabular}{|c|c|c|c|}
\hline & & $\begin{array}{c}\text { Porosidad } \\
\text { (Porosity) } \\
\text { (\%) }\end{array}$ & $\begin{array}{c}\text { Densidad } \\
\text { (Bulk density) } \\
\left(\mathrm{g} / \mathrm{cm}^{3}\right)\end{array}$ \\
\hline \multirow{2}{*}{ SPC } & $\begin{array}{l}\text { Media } \\
\text { (median) }\end{array}$ & 26,6 & 1,99 \\
\hline & $\begin{array}{l}\text { Intervalo } \\
\text { (interval) }\end{array}$ & $17,7-31,7$ & $1,80-2,15$ \\
\hline \multirow{2}{*}{ SP } & $\begin{array}{l}\text { Media } \\
\text { (median) }\end{array}$ & 38,03 & 1,69 \\
\hline & $\begin{array}{l}\text { Intervalo } \\
\text { (interval) }\end{array}$ & $35,1-39,7$ & $1,63-2,02$ \\
\hline \multirow{2}{*}{ SE } & $\begin{array}{l}\text { Media } \\
\text { (median) }\end{array}$ & 0,79 & 2,61 \\
\hline & $\begin{array}{l}\text { Intervalo } \\
\text { (interval) }\end{array}$ & $0,5-1,1$ & $2,60-2,63$ \\
\hline
\end{tabular}


Además de estos dos litotipos se han empleado, de forma muy localizada y generalmente con fines ornamentales, materiales de muy diversas procedencias.

\section{MORFOLOGIA MACROSCÓPICA DE LAS ALTERACIONES}

Se hará una descripción por fachadas, comenzando por la principal, orientada al suroeste. Dentro de cada fachada, tras unas consideraciones previas acerca de los materiales de construcción empleados, clima, urbanismo, ambiente y agentes biológicos, lo que puede orientar acerca de los factores de alteración que pueden intervenir, se hace una descripción de los indicadores visuales de alteración, siguiendo un criterio ordenado en el cual se estudian las modificaciones superficiales, disyunciones, deformaciones, eliminaciones de materia y rupturas, empleando para ello los términos sistematizados por los autores (5).

Hay que señalar que la descripción que a continuación se realiza corresponde al estado que presentaba el Conjunto Catedralicio antes de las tareas de restauración realizadas recientemente; no obstante, este estudio puede ser una oportuna referencia a la hora de llevar a cabo un seguimiento de esas intervenciones.

\subsection{Fachada principal}

\subsubsection{Examen visual de alteraciones correspondientes al Sagrario}

La pidra utilizada en su construcción es la caliza de Santa Pudia, excepto en las cornisas, en la parte correspondiente al goterón, en las que se ha empleado la caliza compacta de Sierra Elvira; son de naturaleza diferente las columnas y figuras que decoran la Portada. La naturaleza química y mineralógico-petrográfica de estos materiales se considera aparte.

Los zócalos del edificio han sufrido restauraciones, empleándose en las mismas una piedra mucho más compacta de grano muy fino; en ocasiones se han sustituido sillares completos y en otras aplacados (Fig. 1a). En general, estas restauraciones se conservan bien actualmente, salvo la pérdida de parte del cemento que une los sillares. Por encima de estas dos hiladas y también a partir del zócalo y las dos hiladas siguientes hacia la esquina izquierda, la fachada está cubierta de un enlucido con imitación de llagueado. En la parte que no está enlucida, correspondiente a la pilastra y a la continuación hacia la derecha de la pared, la piedra muestra la alteración que en su día quizás justificó el enlucido de la otra parte.
Besides these two stone types, other stony materials from diverse provenance have been used in the building, generally for ornamental ends.

\section{MACROSCOPICAL MORPHOLOGY OF THE DETERIORATIONS}

A description by façade will be given starting with the main one facing South West. Witin each façade, after previous considerations on the materials used in construction, climate, urbanism, enviroment and biological agents, what can orientate about the factors of deterioration that intervene, a description of the visual indicators of deteriorations is made following a methodical criteria in which the superficial modifications, deformations disjunctions, elimination of material and ruptures are studied using the systematized terms by the authors (5).

We must point out that the following description corresponds to the state of the Cathedral group before recent restauration works were carried out; however, this study could be an opportune reference at the time of following these interventions.

\subsection{Main Façade}

\subsubsection{Visual examination of deteriorations corresponding to the Sagrarium}

The stone used in its construction is a limestone from Santa Pudia, except on the grooves on the cornices in which a compact limestone from Sierra Elvira was used; the columns and Portal figures are of a different nature. The chemical and mineral-petrografical nature of these materials will be considered apart.

The socles have undergone restorations, using a finely grained more compact stone in them; on some occasions complete ashlars have been substituted and on others placated (figure 1a). In general, these restoration are still well conserved except for the loss of some cement in one of the ashlars. The façade is covered by plaster with sore imitation above these two rows and as from the socle and the following two rows towards the left corner. In the non-plastered part corresponding to the pilaster and the continuation towards the right of wall, the stone shows deterioration which in its day justified the plaster on the other part. 


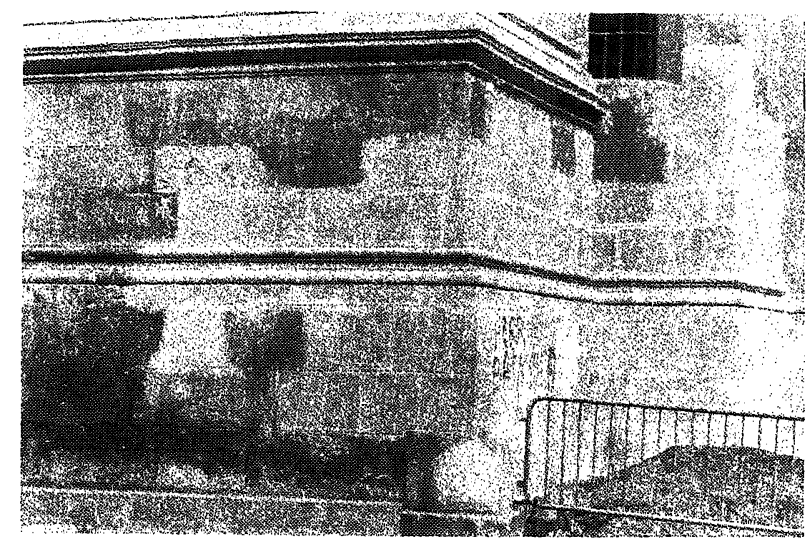

a) Sustituciones en sillares.

a) Substitutions in ashlars.

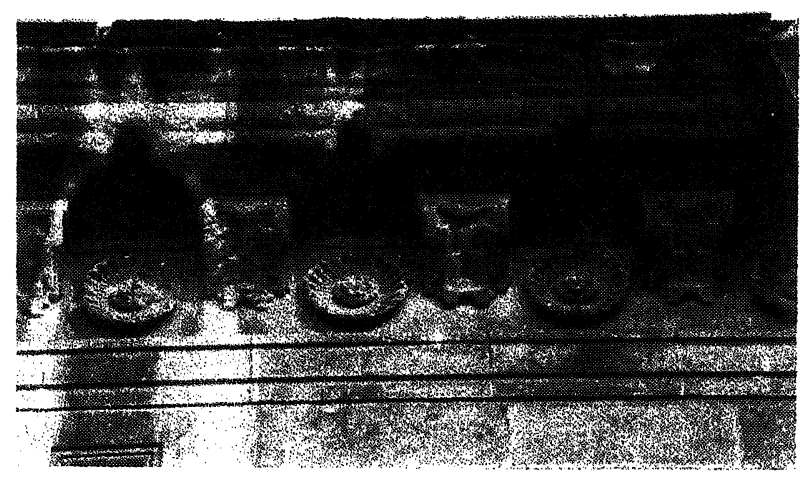

c) Arenizaciones bajo la cornisa.

c) Grain disgregations below the cornise.

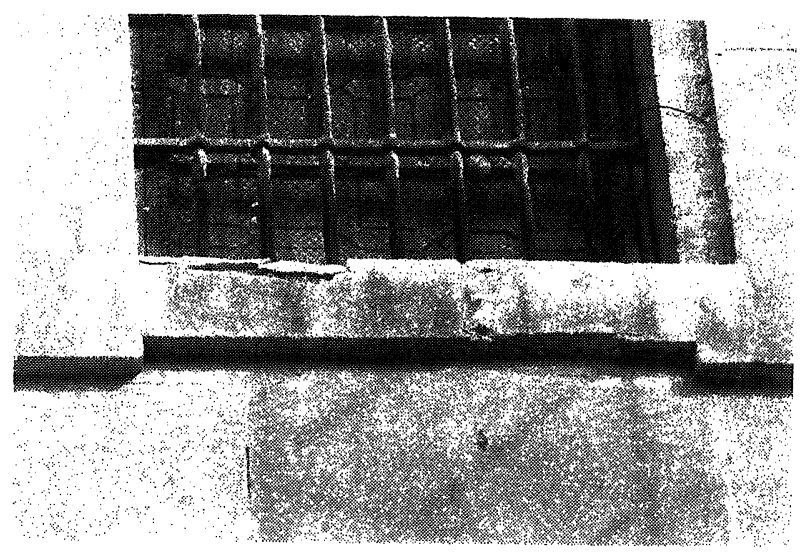

e) Fragmentaciones en la ventana.

e) Spalling in the window.

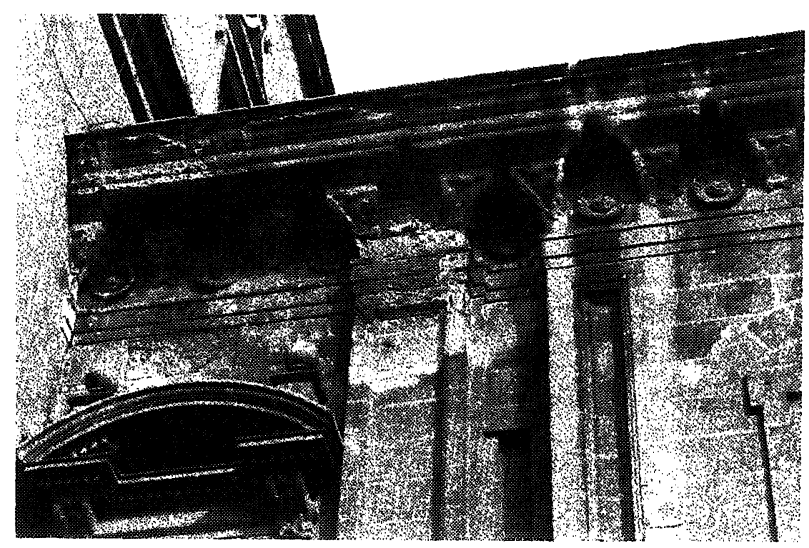

b) Eflorescencias bajo la cornisa

b) Eflorescences beneath the cornise.

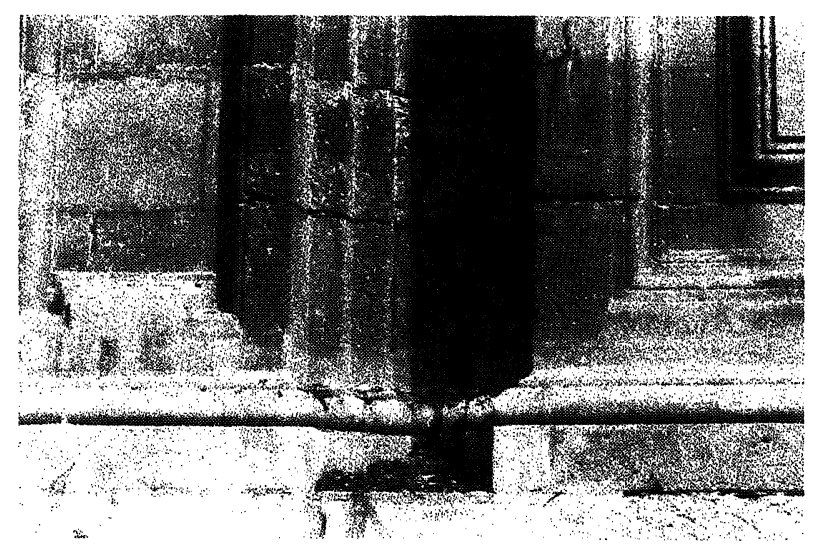

d) Picados en zonas bajas.

d) Pittings in lower areas.

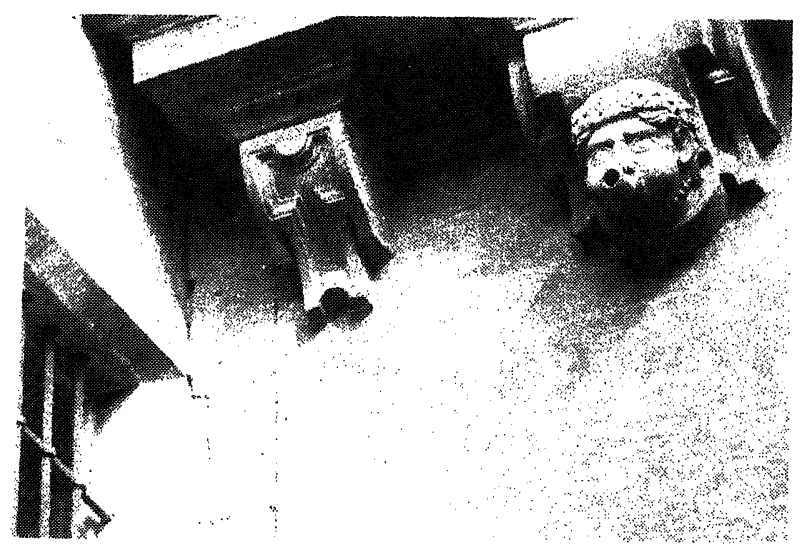

f) Fisura por terremotos o carga.

f) Fissures caused by earthquakes or burdens.

Fig. 1.--Indicadores visuales de alteración. Fachada del Sagrario.

Fig. 1.-Visual indicators of deterioration. Sagrarium façade. 

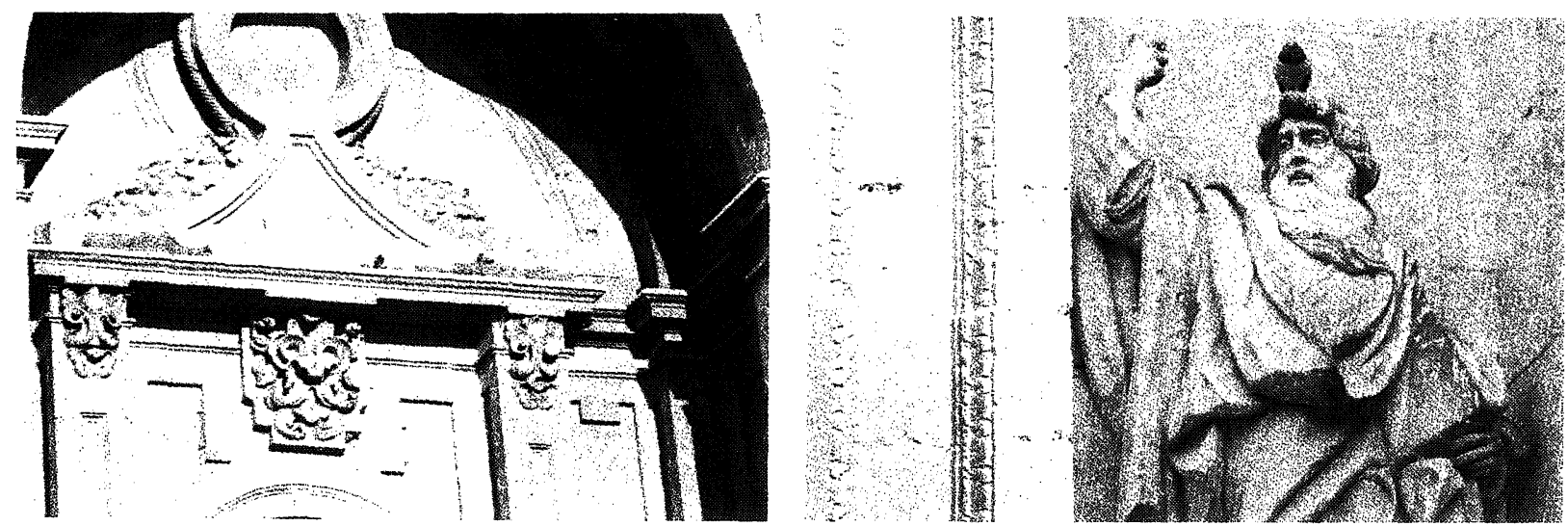

a) Abundantes depósitos de guano

b) Depósitos de guano en estatuas

a) Abundant deposits of bird dung.

b) Deposits of bird dung on statues.
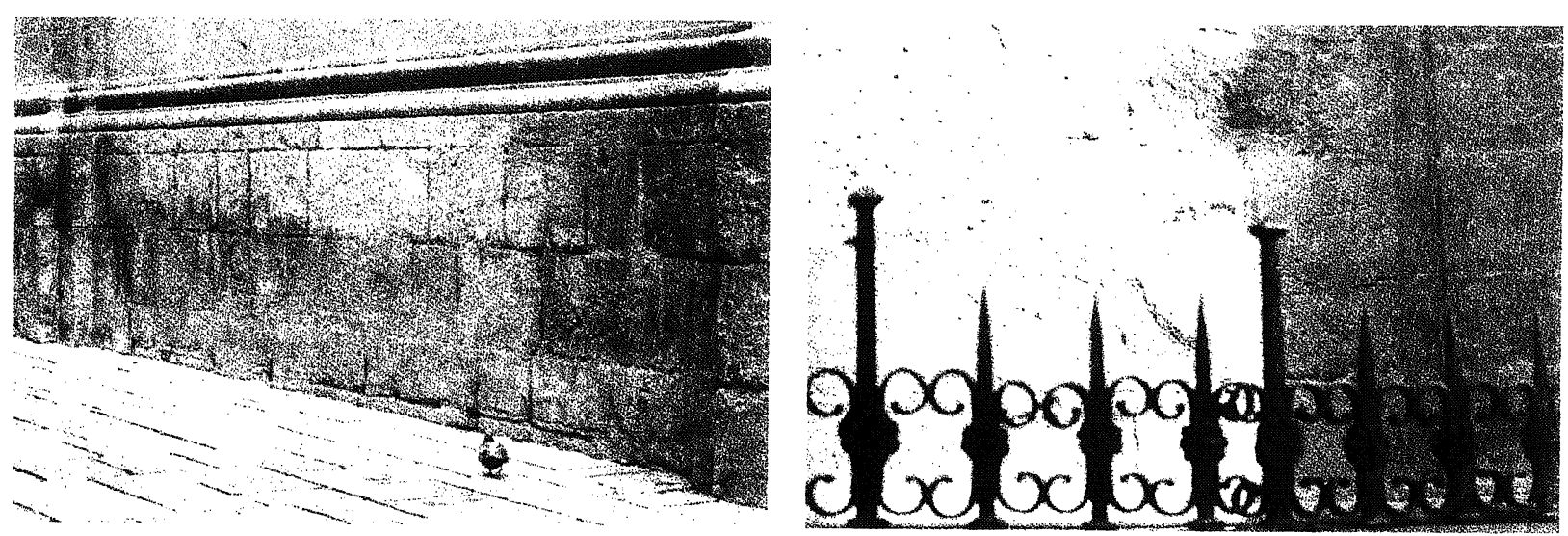

c) Arenizaciones por humedad ascendente.

d) Arenizaciones esporádicas en sillares.

c) Grain disgregations due to rising damp.

d) Sporadic grain disgregations on the ashlars.
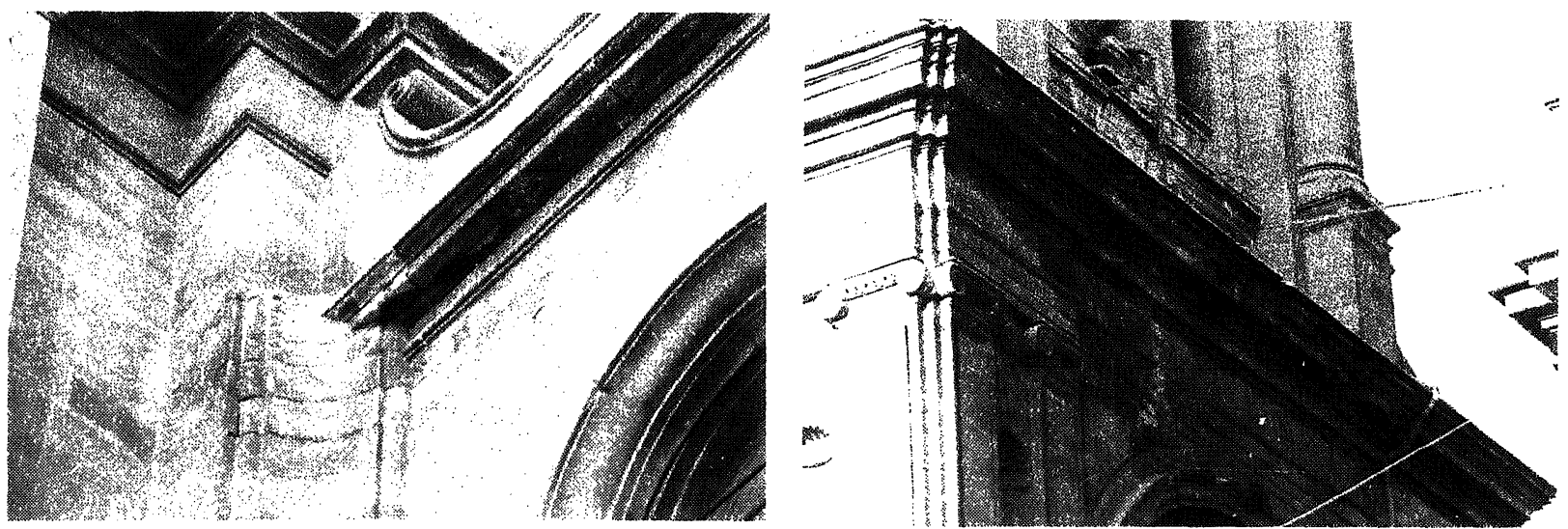

e) Arenizaciones junto a cornisas

f) Picados y alveolizaciones en la torre

e) Grain disgregations next to the cornises.

f) Pitting and alveolar erosions on the tower

Fig. 2.-Indicadores visuales de alteración. Fachada principal de la Catedral

Fig. 2. - Visual indicators of deterioration. Main façade of the Cathedral 
Se observan depósitos de polvo, sobre todo debajo de las cornisas, así como depósitos de guano de palomino en las superficies horizontales. En zonas localizadas, como en el rincón adyacente a la Catedral y debajo de la cornisa, aparecen eflorescencias (Fig. 1b).

En ésta zona próxima a la Catedral se localizan las más importantes arenizaciones, especialmente en superficies barridas por el agua procedente de roturas de la cornisa (Fig. 1c), y en las jambas de las ventanas.

En las zonas bajas no enlucidas, se observan picados (Fig. 1d).

Los elementos de piedra de Sierra Elvira de las cornisas tienen abundantes fracturaciones con episodios de pérdidas importantes de fragmentos, hecho que se repite con menos frecuencia en algunos sillares aislados y en el alféizar de una ventana (Fig. 1e). La magnitud de este proceso de fragmentación ha exigido una intervención de emergencia por medidas de seguridad. En el rincón adyacente a la Catedral, una fisura de gran extensión parece haber sido provocada probablemente por terremotos o cargas del edificio (Fig. 1f).

\subsubsection{Examen visual de alteraciones correspondientes a la Catedral}

El tipo de piedra utilizado en esta fachada de la Catedral es exclusivamente de Santa Pudia. Hay que señalar, sin embargo, que en los zócalos se han realizado restauraciones al parecer mezclando morteros con piedra de Santa Pudia o al menos dándole color de forma que la apariencia externa es parecida. Las decoraciones escultóricas existentes en la portada son de una piedra mucho más blanca.

Esta fachada, por su orientación suroeste, está bien soleada. Se encuentra precedida por una gran plaza flanqueada a la izquierda, bajo la torre, por una calle estrecha, y a la derecha por otra de mayor anchura.

No parece existir una gran contaminación armosférica en esta zona peatonal.

La humedad ascendente del suelo es escasa y ha alcanzado en algunas ocasiones la altura de los zócalos y a veces algo más. En el rincón donde termina la parte derecha de la portada se observa una gran mancha de humedad, cuyo origen se desconoce, que alcanza hasta el óculo.

Esta fachada es la mejor conservada de las cuatro, teniendo mucha menor entidad los indicadores de alteración.
Deposits of dust were observed above all beneath the cornises as well as pigeon dung deposits on the horizontal surfaces.

Efflorescences appear in certain areas such as in the nook adjacent to the Cathedral or beneath the cornice (Fig. 1b).

The most important grain disgregations are located in this area near the Cathedral especially on the surfaces swept by water from breaches in the cornice (Fig. 1C) and in the window-jambs.

Pitting is seen (Fig. 1d) in the non-plastered lower areas.

The stone elements from Sierra Elvira on the cornises have abundant fractures with episodes of important losses of fragments a fact which is repeated less frequently in some isolated ashlars and a window embrasure (fig. 1e). The magnitud of this spalling process has called for an emergency intervention for security measures. A greatly extended fissure in the nook adjacent to the Cathedral seems to have been provoked by earthquakes or building strain (fig. 1f).

\subsubsection{Visual examination of deteriorations corresponding to the Cathedral.}

The type of stone used on this façade of the Cathedral is exclusively from Santa Pudia. However, we must point out that restorations have been carried out in the socles apparently mixing mortars with Santa Pudia stone or at least giving them a similar external appearance in colour. The existing sculptural decorations on the portal are of a much whiter stone.

This façade, owing to its orientation, is well sunned. A great square precedes it flanked by a narrow street, under its tower, on the left and by a wider one on the right.

There does not seem to be great atmospherical pollution in this pedestrian area.

The rising damp from the ground is scarce although it has reached the socles and a little higher on some ocassions. A great damp stain can be seen in the corner where the right part of the portal ends. Its origin is unknown and it reaches up to the oculus.

This façade is the best conserved of the four having less indicators of deterioration. 
Sólo aparecen líquenes en las superficies horizontales y rampantes, así como en los antepechos que coronan esta fachada. Los líquenes se encuentran extendidos por todas las cúpulas y antepechos, excepto en las restauraciones con mortero.

Llaman la atención por su abundancia y repercusiones estéticas, los depósitos de guano de palomino (Fig. 2a) que afectan a todas las molduras y superficies salientes, así como a las figuras escultóricas (Fig. 2b), dando una desagradable impresión de abandono. También se observan depósitos de polvo en todos los paramentos, especialmente en las zonas bajas, donde además se encuentran antiguas pintadas de color rojo, $y$ en los elementos decorativos que coronan esta fachada en la orientación nordeste.

Toda la fachada presenta una fuerte pátina debida al paso del tiempo, que contrasta fuertemente con las zonas recientemente restauradas.

Las disyunciones más importantes están asociadas a aplicaciones de morteros utilizados para reparar elementos muy degradados. EI tiempo ha mostrado su escasa adherencia provocando importantes daños en el material subyacente.

En las zonas afectadas por la humedad ascendente se observan arenizaciones, sobre todo en las juntas entre sillares en que se ha producido algún redondeamiento de las aristas (Fig. 2c). En algunos sillares aislados y en zonas cercanas a cornisas se observan también pérdidas de materia provocadas por estas arenizaciones (Fig. $2 d$ y e).

Los picados y alveolizaciones se dan en mayor profundidad en los antepechos y en la torre (Fig. 2f).

Las rupturas, tanto en forma de fracturas como de fisuras y fragmentaciones, surgen de dos etiologías bien diferenciadas. Por un lado, las asociadas a fenómenos fisicoquímicos como los ciclos de cristalización de sales y de humidificación-secado, así como los de heladicidad que afectan sobre todo a molduras y otros elementos decorativos. Por otro lado, las asociadas a la expansión por oxidación de hierros utilizados como espigas de sujeción de pináculos o incluso de clavos de fijación de aisladores eléctricos.

\subsection{Fachada Oeste}

Realmente se encuentra orientada al noroeste. Como en toda la Catedral, la piedra mayoritariamente empleada en esta fachada es de Santa Pudia.
Lichens only appear on the horizontal surfaces and ramps as well as the breastwork which crowns this façade. Lichens are spread all over the dones and breastwork except on the mortar restorations.

The pigeon dunp deposits (fig. 2a) are outstanding for their abundance and estethical repercussions and affect all the moldings and projecting surfaces as well as the sculptural figures (fig. 2b) giving an unpleasant impression of negligence. Dust deposits were also observed on all the adornments specially on low areas, where ancient red paints are also found and on the decorative elements which crown this façade facing North East.

All the façade shows a strong patina due to the passing of time which contrasts greatly with the recently restored areas.

The most important disjunctions are associated to the application of mortars used to repair badly degraded elements. Time has shown its little adherence and so provoking important damage in the underlying material.

Grain disgregations are seen in the areas affected by rising damp above all in the joints between ashlars in wich the arris have been rounded off (fig. 2c). In some isolated ashlars and areas near the cornices, losses of material provoked by these grain disgregations have been observed (fig. $2 d \&$ e).

Pitting and alveolar erosions are deeper in the breastwork and the tower (fig. 2f).

The ruptures in the form of cracks as well as fissures and spalling, originate from two well-defined aetiologies. On one hand those associated with physicochemnical phenomena such as the salt crystallization and wet-dry cycles as well as those of freezing which affect the moldings and other decorative elements. On the other hand, those associated with expansion through iron oxidation such as fastening spickes for pinnacles or even fastening nails for electrical insulators.

\subsection{Western façade}

Its is really orientated to the North West. The stone mainly used on this façade is from Santa Pudia as on all the Cathedral. 

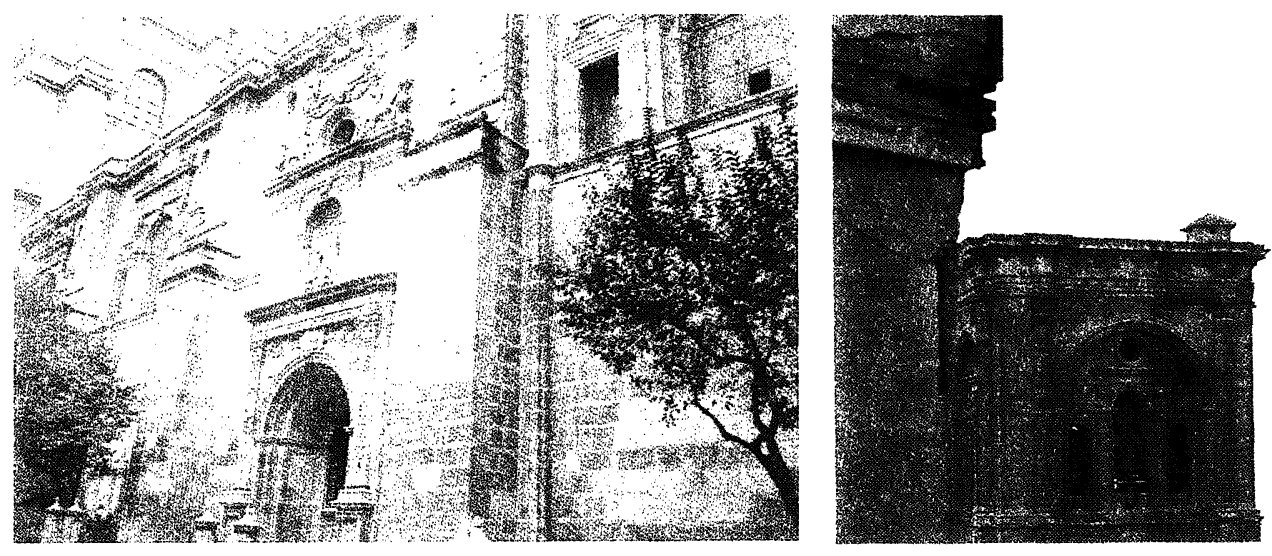

a) Pátina en sillares originales.

b) Disyunciones en morteros.

a) Patina on the original ashlars.

b) Disjunctions in mortars.
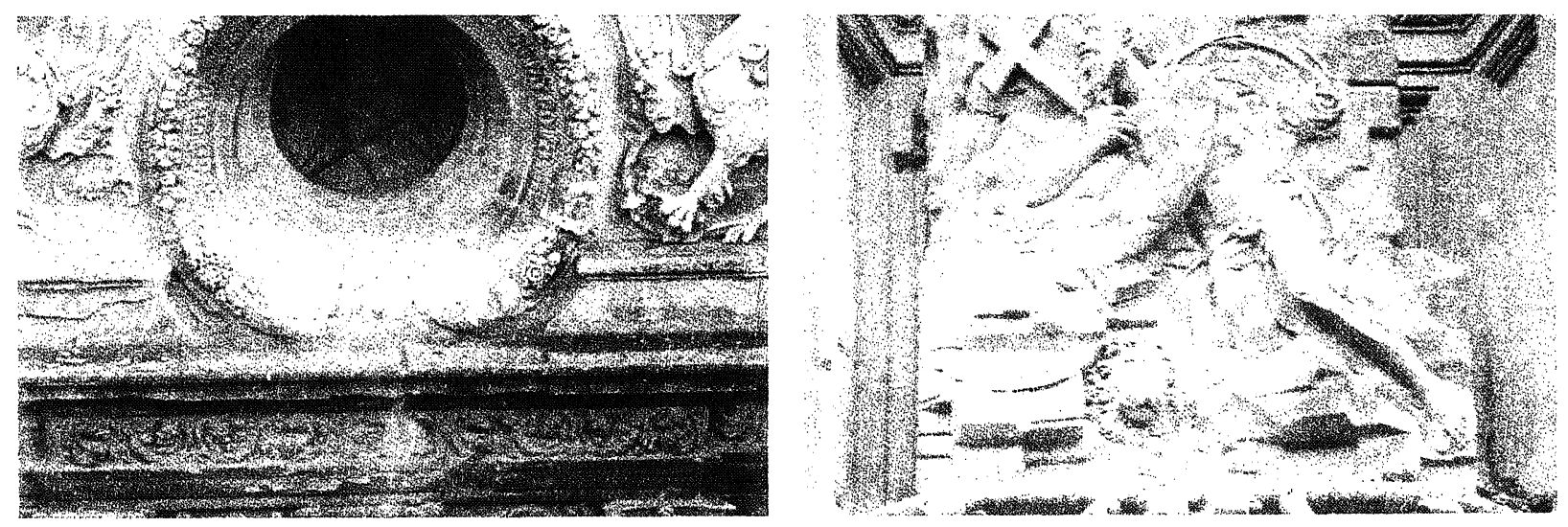

C) Disyunciones y arenizaciones.

d) Disyunción de costra y arenización.

c) Disjunctions and grain disgregations.

d) Crusting disjunction and grain disgregation.
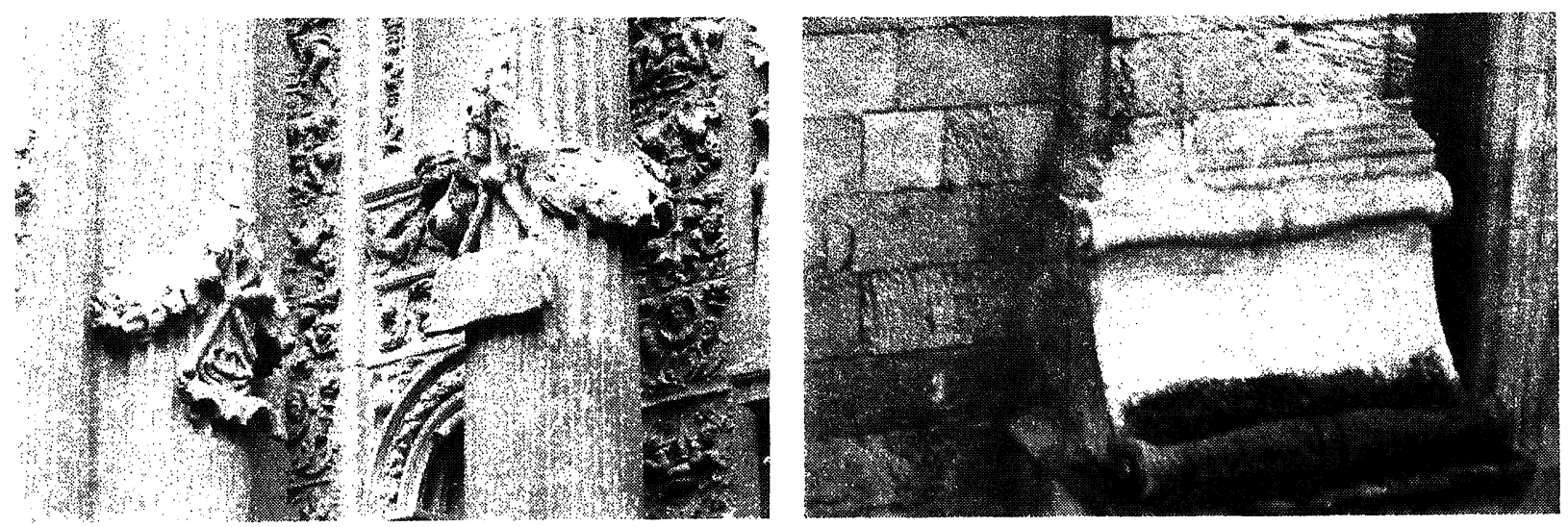

e) Arenizaciones en zonas lavadas.

f) Picados y estriados.

e) Grain disgregations on washed areas.

f) Pittings and grooves.

Fig. 3.-Indicadores visuales de alteración. Fachada oeste (Lámina 1).

Fig. 3.-Visual indicators of deterioration. Western façade (llustration 1). 


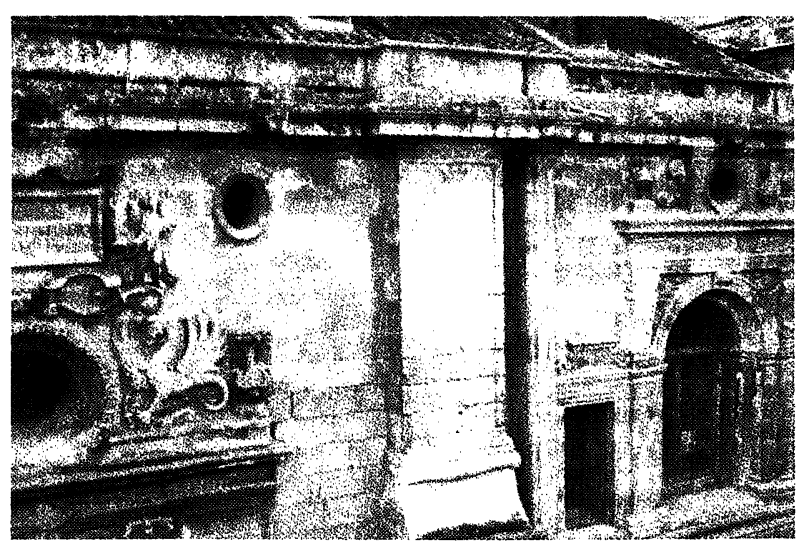

a) Huecos diversos en toda la fachada.

a) Diverse holes on all the façade.

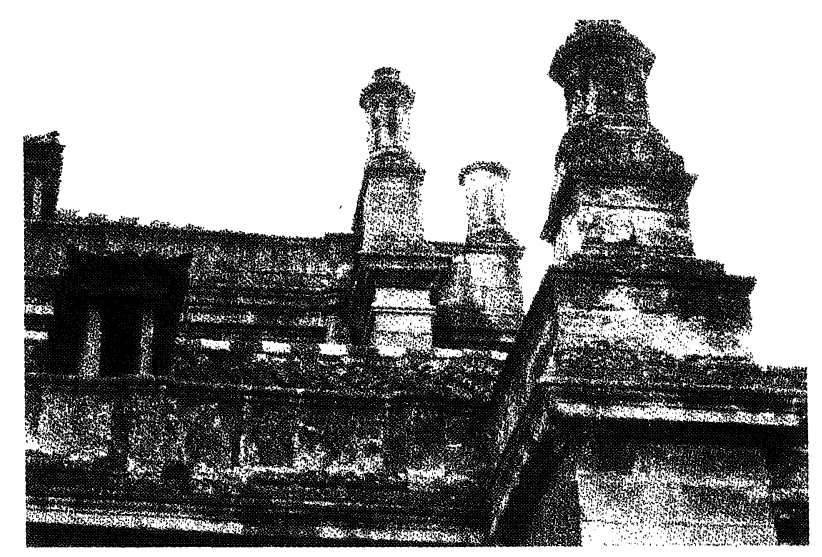

c) Picados y arenizaciones en pináculos y sillares.

c) Pittings and grain disgregations on pinnacles and ashlars.

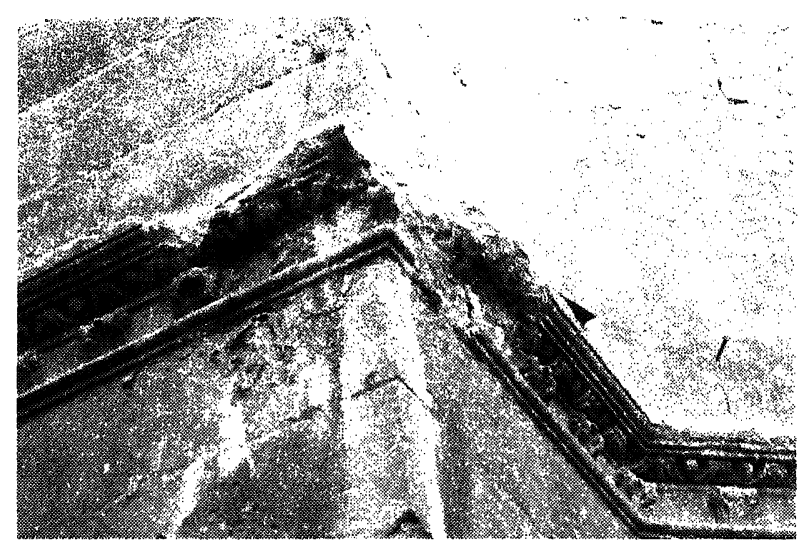

e) Fragmentaciones en molduras y separación de películas.

e) Spalling on mouldings and film disjuntions.

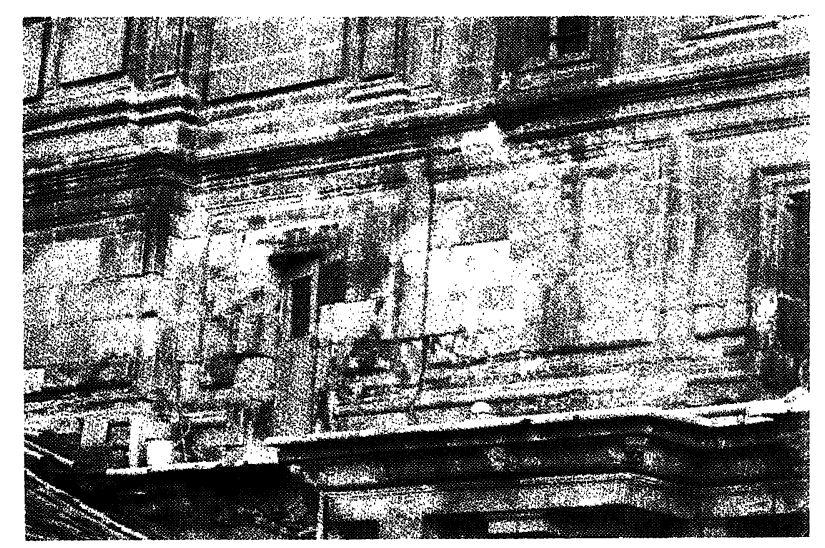

b) Picados y arenizaciones en la torre.

b) Pittings and grain disgregations on the tower.

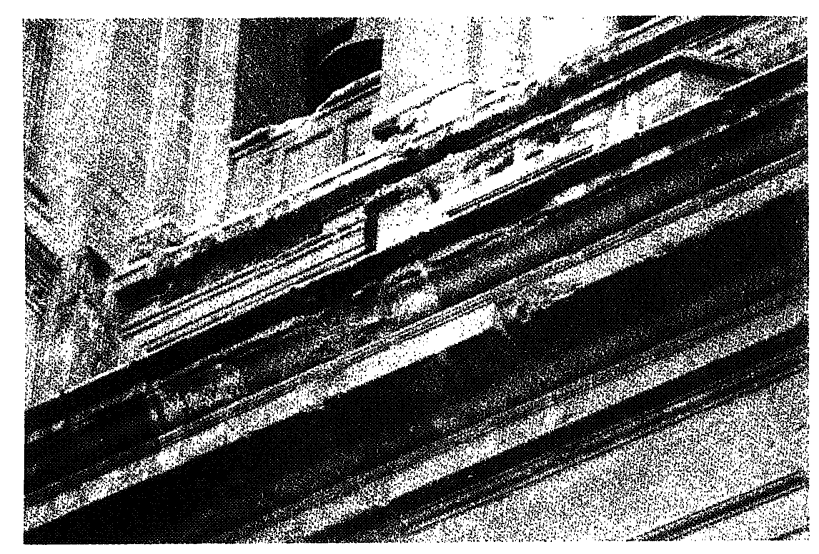

d) Diversas pérdidas de material en cornisas.

d) Loss of material on the cornises.

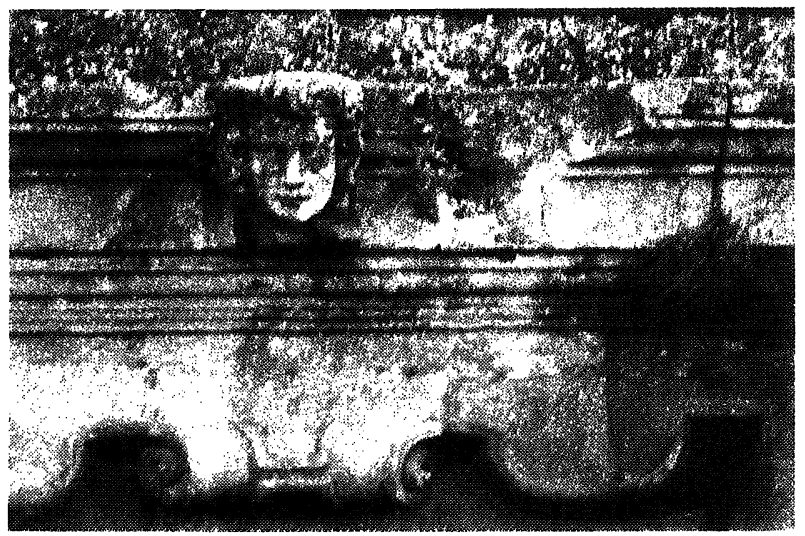

f) Fracturaciones y fragmentaciones en cornisas.

f) Cracks and spallings on the cornises.

Fig. 4.-Indicadores visuales de alteración. Fachada oeste (Lámina 2).

Fig. 4.-Visual indicators of deterioration. Western façade (llustration 2). 
Destacan en esta fachada las desafortunadas y sucesivas restauraciones en una gran parte de las zonas bajas del edificio. En dichas restauraciones se han utilizado materiales de diverso tipo, que han roto la armonía de color del edificio (Fig. 3a) y no han impedido, en general, el avance de la acción degradante de la humedad: morteros imitando el color original de la piedra, sustitución de sillares completos, simples aplacados e incluso hormigón y ladrillos recubiertos con este mortero. En ocasiones, se han empleado también morteros para reconstruir molduras, relieves, etc., como puede observarse en la parte inferior de las pilastras de la Portada de San Jerónimo.

Esta fachada, por su orientación noroeste, recibe el sol en las últimas horas de la tarde y solamente en los cuerpos superiores, dado que la calle adyacente es estrecha y las casas vecinas dejan las partes inferiores permanentemente a la sombra. Por esta razón, la humedad es grande, favorecida por el agua ascendente por capilaridad, que en la zona de la torre alcanza hasta 1 metro de altura, y en el ángulo opuesto llega a alcanzar hasta dos metros; contribuye a ella también una fuente entre las Portadas de San Jerónimo y del Perdón. Los antepechos y las bases de los pináculos de los cuerpos superiores están también húmedos.

El desarrollo de agentes biológicos, obviamente, es abundante. Los líquenes, e incluso musgo, se extienden por dichas zonas, en las que crecen también algunas plantas superiores. Rodeando la fachada, y a corta distancia de los muros, han sido plantados árboles, actualmente de escaso porte.

En la calle existe un tráfico rodado discreto, que no parece contaminar excesivamente el aire.

Las modificaciones superficiales más relevantes consisten en la fuerte pátina producida por el paso del tiempo, hecho observable en el contraste de color que ofrecen los sillares sustituidos (Fig. 3a), en las placas y costras de origen biológico y en los depósitos de polvo, y tal vez de inquemados, especialmente en el paramento nordeste de la torre.

Las disyunciones más importantes se producen en las placas y costras antes mencionadas y también se observan algunas descamaciones en el cuerpo de la torre de campanas, aunque éstas parecen ser desprendimientos de un encalado. Asi mismo, se observan disyunciones en las reconstrucciones realizadas con morteros (Fig. 3b y c) y separación de películas bajo las cornisas (Fig. 4e).

Tanto debajo de las disyunciones mencionadas, como en zonas que reciben el agua de cornisas
The unfortunate and successive restorations on a large part of the lower areas of the building are prominent. Materials of a different type have been used in said restorations which have broken the colour harmony of the building (fig. 3a) and, in general, have not impeded the advance of the degradation by humidity: mortars imitating the stone original colour, substitution of whole ashlars, simple plaqueting and even cement and bricks covered with this mortar. On some ocassions, mortars have also been employed to reconstruct mouldings, reliefs, etc as can be observed on the lower part of the pilasters on the San Jerónimo portal.

This façade, due to its North Western orientation, only receives sun during the late hours of the afternoon and only on its higher bodies, as the adjacent street is narrow and its houses leave its lower parts permanently in shade. For this reason the damp is great, favoured by the rissing water through capillary attraction, which reaches up to 1 metre high in the Tower area and 2 metres high in the opposite angle. $A$ fountain between the San Jerónimo and Perdón portals also contributes to this. The parapets and bases of the pinnacles on the higher bodies area also damp.

The development of biological agents is obviously abundant. Lichens and even moss, are widespread in said area, in which some superior plants also grow. Trees have been planted surrounding the façade at a short distance from the walls although of little portage.

There is a slight circulating traffic in the street which does not seem to excessively contaminate the air.

The most relevant superficial modifications consist in a strong patina produced by the passing of time, a fact seen in the colour contrast in the substituted ashlars (fig. 3a), in the plaques and crusting of biological origin and the dust deposits and perhaps unburnt materials specially on the north eastern adornment of the tower.

The most important disjunctions are produced on the above mentioned plaques and crusting and some dasquamations are also seen on the body of the bell-tower although these seem to be whitewash loosenings. At the same time, disjuntions on the reconstructions using mortars (fig. $3 b \& c$ ) and film separations under the cornices (fig. 4e) are seen.

Grain disgregations are produced under the aforementioned disjuntions as well as the areas 
superiores, se producen arenizaciones, que en ocasiones afectan gravemente a las decoraciones escultóricas (Fig. 3d y e).

Los huecos, tanto en forma de picados y alveolizaciones como de estriados, están ampliamente extendidos en la fachada (Fig. 3f y 4a). Estos indicadores aparecen frecuentemente unidos a las arenizaciones, lo que conduce a abundantes pérdidas de materia, como se manifiesta en cornisas, antepechos, pináculos, etc; en general, en todos aquellos lugares en que actúan simultáneamente la humedad y el viento (Fig. 4b, c y d).

Las molduras, bordes de cornisas y ángulos se ven afectados por gran número de fragmentaciones (Fig. $4 \mathrm{e}$ y $4 \mathrm{f}$ ).

\subsection{Fachada Norte}

Realmente se encuentra orientada al nordeste. Además de la piedra de Santa Pudia, que con carácter general se ha empleado en la construcción de todo el edificio, las tres hiladas de sillares adyacentes al suelo son de una arenisca de color amarillo oscuro. En la Portada del Colegio se aprecian también piedras de naturaleza diferente, como son unos granitos en las dos semicolumnas que la flanquean y unos mármoles en los pedestales de los mismos. Como en la fachada noroeste, son abundantes las reparaciones con morteros de diverso tipo.

Debido a su orientación al nordeste, se encuentra muy poco soleada. La calle adyacente, peatonal, se encuentra separada de la Gran Vía, de alta densidad de tráfico, por una manzana de edificios de cinco plantas cuya altura corresponde aproximadamente a la de los dos niveles inferiores, ejerciendo así un efecto de apantallamiento a los humos debidos a dicho tráfico.

La humedad ascendente alcanza aproximadamente un metro de altura, algo superior a la de los sillares sustituidos.

Son abundantes los desarrollos de algas, sobre todo en la Portada del Colegio, así como en una zona de gran humedad, debida posiblemente a desagües defectuosos. También los musgos forman una espesa placa biológica; algunas plantas superiores crecen en determinadas zonas. Los líquenes encuentran su más amplio desarrollo en las superficies rampantes y horizontales de los niveles altos (quiebras, molduras de pináculo...).

Una fuerte pátina oscurece en toda la fachada el color natural de la piedra. Es llamativo el efecto que sobre la misma ha ejercido la protección de una casa antiguamente adosada a esta fachada (Fig. 5a). which receive water from the higher cornices, which seriously affects the sculptural decorations on ocassions (fig. $3 d \& e$ ).

Holes are widespread on the façade in the form of pitting and alveolar erosions as well a striations (figs. 3f \& 4a). These indicators often appear united to grain disgregations which leads to abundant losses of material as is seen on cornices parapets, pinnacles, etc: in general in all those places where the wind and damp act simultaneously (figs. $4 b, c \& d$ ).

The mouldings, edges of cornices and angles are affected by a large number of spalling (figs. $4 e$ \& $f$ ).

\subsection{Northern façade}

It is really oriented to the Nort East. Besides the Santa Pudia stone, generally used on the building, the theree rows of ashlars adjacent to the ground are constructed of a dark yellow sandstone. Stones of a different nature are seen on the College portal such as granite on two semicolumns which flank them and marble on its pedestals. Repairs carried out with diverse mortars are abundant as on the North West façade.

Due to its northeastern orientation it is not well-sunned. The adjacent pedestrian street is separated from the Gran Via, which has a high density of traffic, by a block of five-storey buildings whose height corresponds approximately to that of the two lowest levels so having a screening effect on the fumes from said traffic.

The rising damp is about one metre high, a little higher than the substituted ashlars.

The development of algae is abundant, above all on the Colegio Portal as well as a very damp area which could be due to bad drainage. Moss also forms a thick biological plaque: some superior plants grow in certain places. Lichens are more widely developed on the ramps and horizontal surfaces of the high levels (cracks, pinnacle mouldings, ...).

A strong patina darkens the natural colour of the stone all over the façade. The effect which an old house joined to this façade has on it is attention-calling (fig. 5a). 


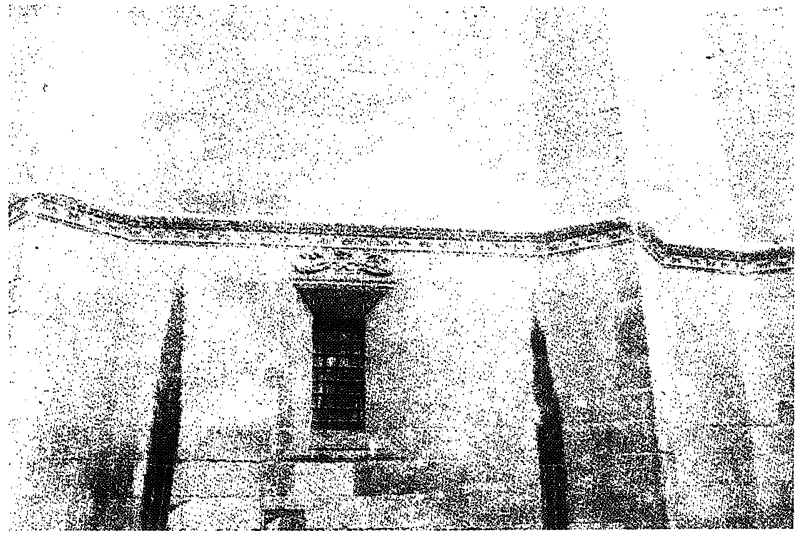

a) Pátina. Efecto de una antigua protección.

a) Patina. Effect from old protection.

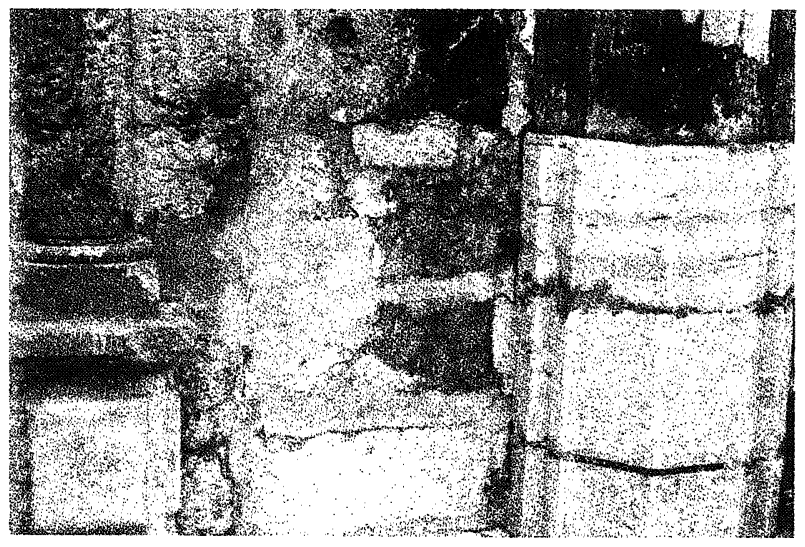

c) Disyunciones de costras.

c) Crust disjunctions.

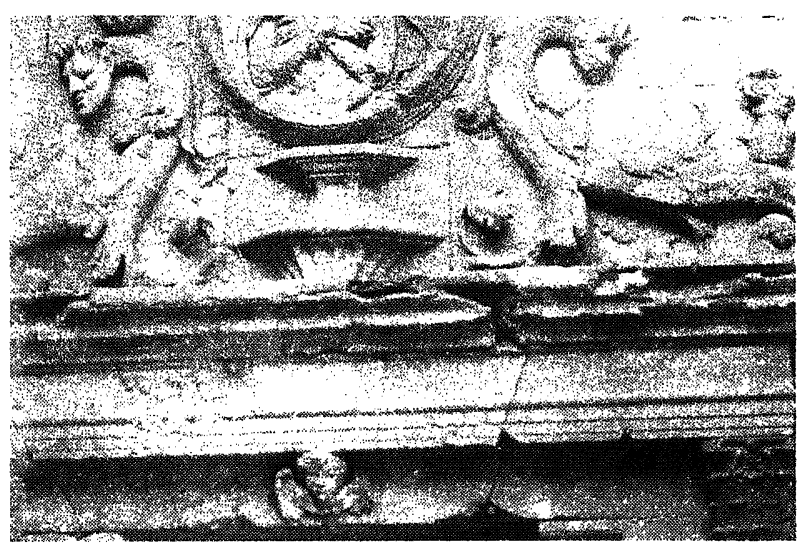

e) Degradaciones diversas en la portada.

e) Different degradations on the portal.

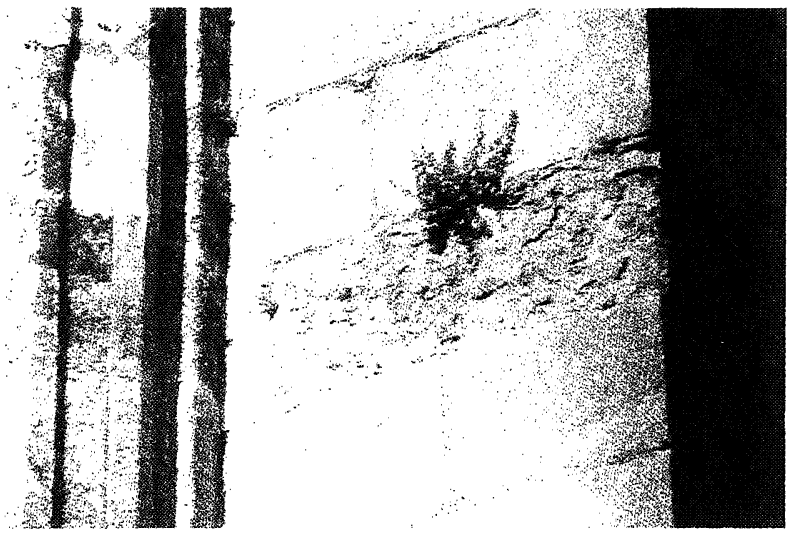

b) Disyunciones de películas.

b) Film disjunctions.

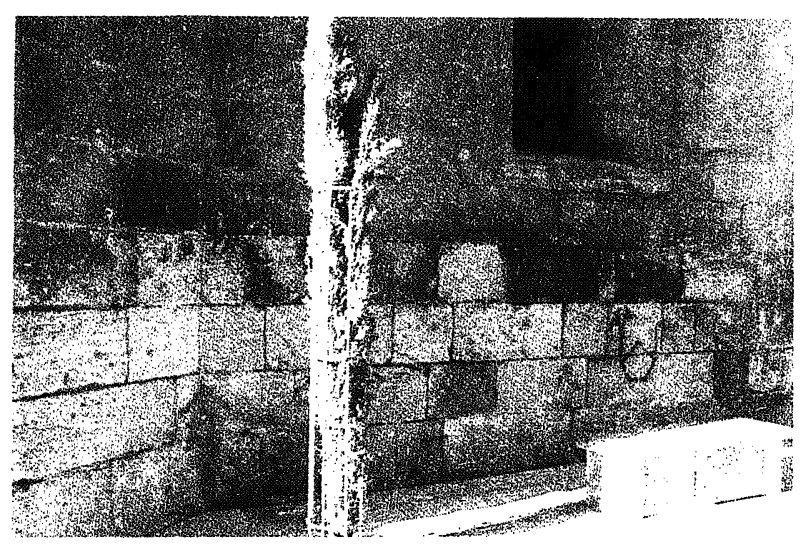

d) Arenizaciones.

d) Grain disgregations.

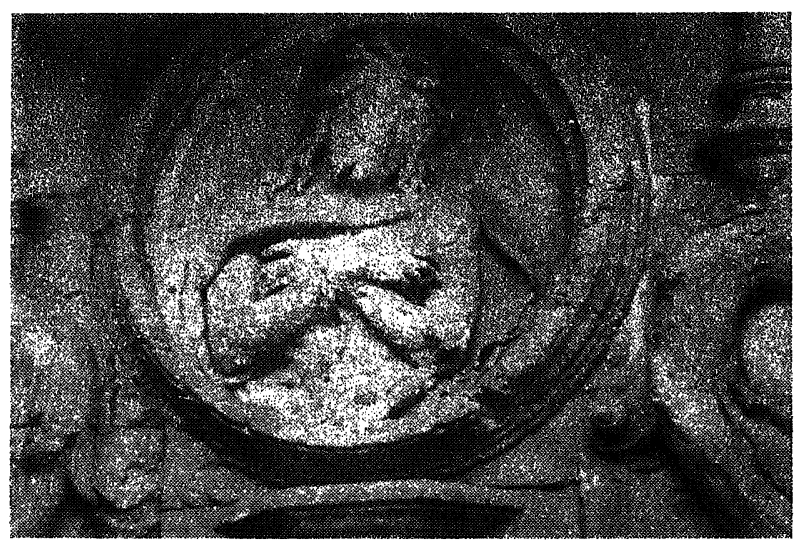

f) Disyunciones y arenizaciones en las figuras.

f) Disjunctions and grain disgregations on the figures.

Fig. 5.-Indicadores visuales de alteración. Fachada norte (Lámina 1).

Fig. 5.-Visual indicators of deterioration. Northern façade (llustration 1). 


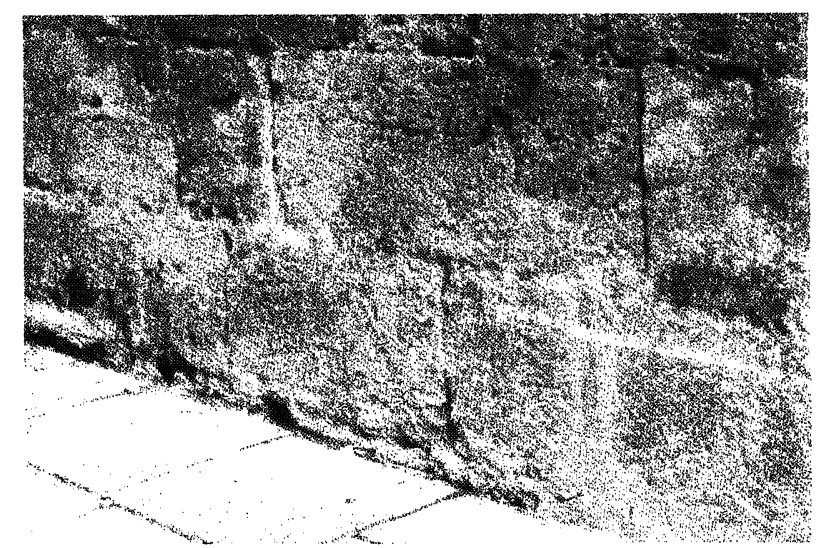

a) Picados y alveolizaciones en zonas húmedas bajas.

a) Pitting and alveolar erosions in lower damp zones.

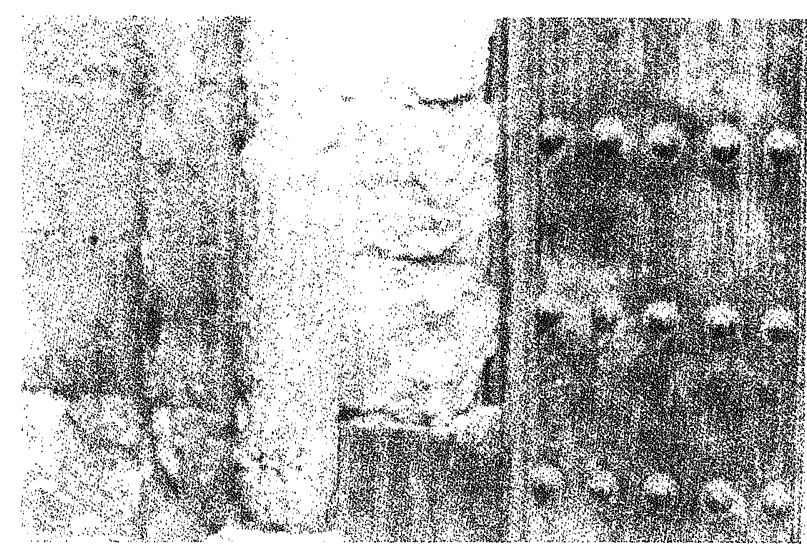

c) Fragmentaciones en columnas y jambas.

c) Spalling in columns and jambs.

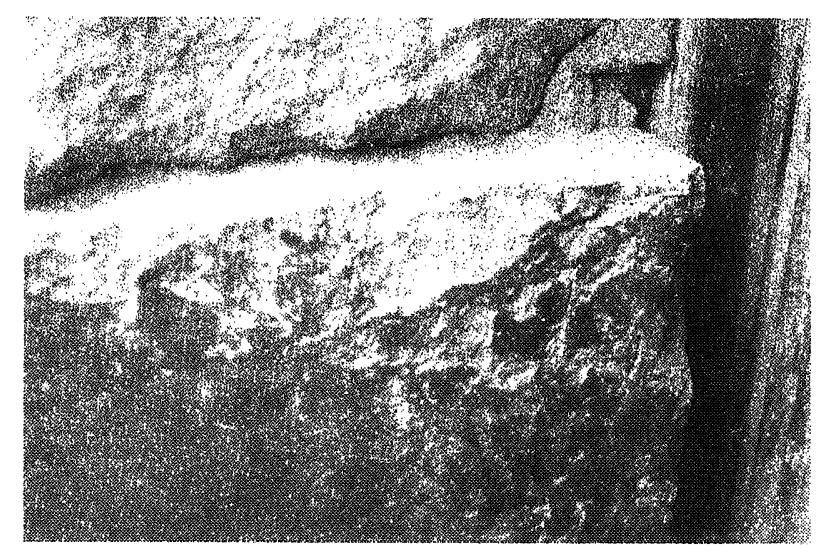

e) Fracturaciones en el mármol.

e) Cracks in the marble.

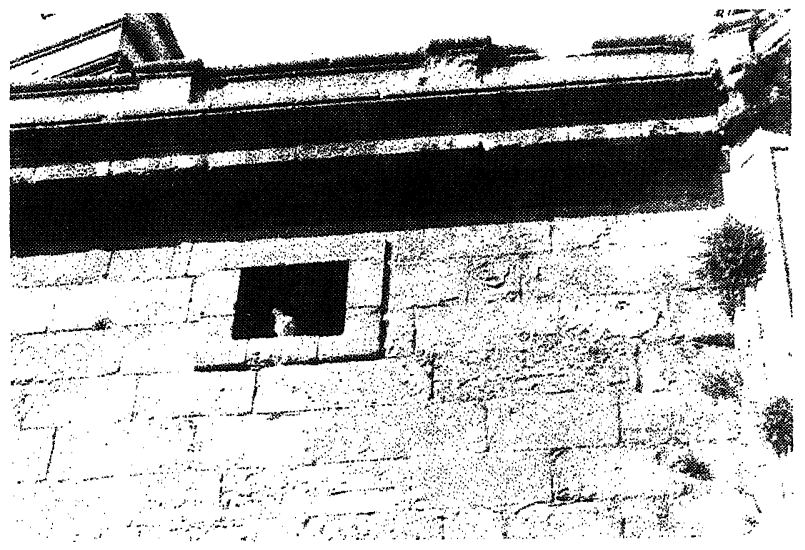

b) Picados y alveolizaciones en zonas aireadas altas.

b) Piting and alveolar erosions in high aired areas.

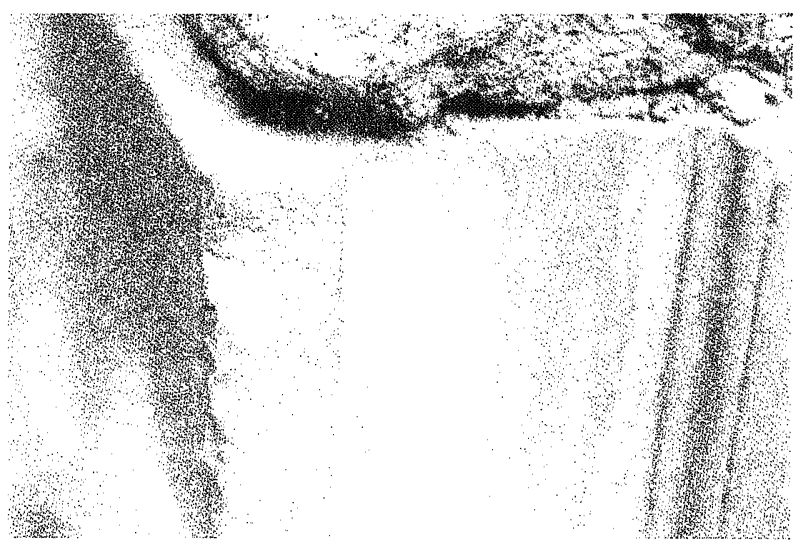

d) Fragmentaciones y descamaciones en el mármol.

d) Spalling and desquamations on the marble.

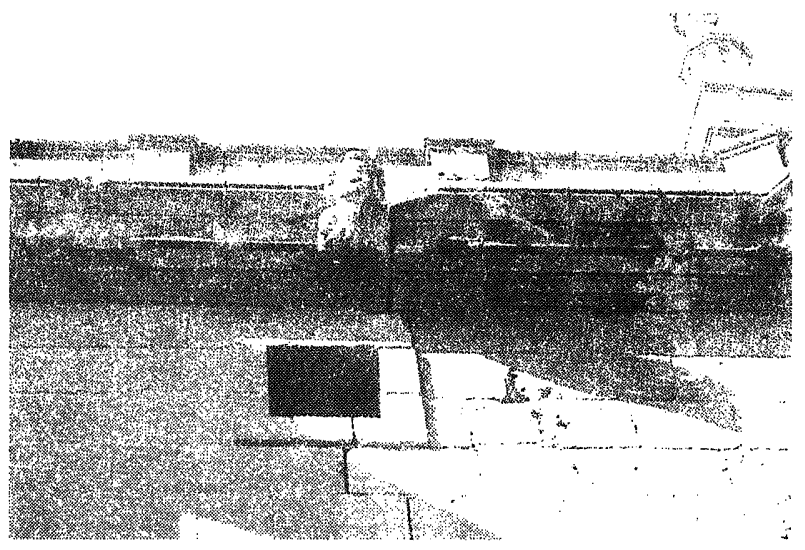

f) Fisuraciones por terremotos o cargas del edificio.

f) Fissures due to earthquakes and building strain.

Fig. 6.-Indicadores visuales de alteración. Fachada norte (Lámina 2).

Fig. 6. -Visual indicators of deterioration. Northern façade (llustration 2). 
En algunas zonas existen depósitos de partículas carbonosas de una morfología que hace pensar en incendios $u$ hogueras. La mayor cantidad de depósitos debidos a partículas del medio ambiente, se encuentra en la superficie situada sobre la Portada del Colegio, precisamente enfrente a una calle que sale a la Gran Vía, y, por tanto, sin el efecto protector de edificios. Además, los volúmenes situados entre ésta calle y la calle Oficios son de pequeña altura.

Además de las usuales disyunciones de películas de inquemados, como muestra la figura $5 b$, los más graves desprendimientos de costras se producen, como cabía esperar, en las restauraciones realizadas con morteros (Fig. 5c).

En todas las zonas afectadas por la humedad se producen graves arenizaciones. Los casos más importantes, por la abundancia de pérdida de materia, se dan en las zonas alcanzadas por la humedad ascendente (Fig. 5d), y que tal vez indujeron a la sustitución de sillares, así como debajo de las cornisas. Son de señalar, por su grave repercusión estética, las producidas en las figuras que decoran la Portada del Colegio (Fig. $5 e$ y f).

Los picados, alveolizaciones y estriados afectan, lógicamente, a las zonas más húmedas y aireadas (Fig. 6a y b).

Los picados, alveolizaciones y arenizaciones se ven acompañados, especialmente en la Portada del Colegio, con fragmentaciones localizadas sobre todo en los ángulos y perfiles salientes (Fig. $6 c)$. En los mármoles de la misma, se han producido rupturas, en forma de pequeños fragmentos y de escamas (Fig. 6d), y abundantes fracturas (Fig. 6e). No faltan en esta fachada ejemplos de fisuras, provocadas probablemente por terremotos, en una ciudad de tan alta actividad sísmica (Fig. 6f).

\subsection{Fachada este}

Realmente se encuentra orientada al sudeste. También el tipo de piedra mayoritariamente utilizado en la construcción de esta fachada es la caliza de Santa Pudia; en las cornisas existen igualmente elementos de caliza de Sierra Elvira. Como en otras fachadas, en las partes bajas se han realizado sustituciones en los paramentos con una piedra bien pulimentada cuyo origen se desconoce. Algunas superficies, como es el caso de la pared de la Lonja, han sido enlucidas con hormigón de cemento portland.

Recibe el sol durante la mañana. No obstante, debido a la proximidad de casas, la zona correspondiente al primer nivel, hasta la primera cornisa que lo corona, se encuentra siempre umbría, excepto el trozo de lienzo situado frente a
In some areas there are deposits of carbonaceous particles whose morphology makes one think of fires or bonfires. The greatest quantity of deposits due to particles from the environment are found on the surfaces situated above the college Portal precisely opposite a street which goes out on to the Gran Via and, so, it does not have the protecting effect of the buildings. Furthermore, the buildings situated between this street and Oficios street are low.

The most serious detachments are found, as expected, in the restorations carried out with mortars (fig. 5c) as well as the usual film disjunctions of unburnt materials as is shown in figure $5 b$.

Serious grain disgregations are found in all the areas affected by dampness. The most important cases, owing to the high loss of material, are in the areas reached by the rising damp (fig. 5d), which perhaps led to the substitution of ashlars, as well as under the cornices. We should point out those produced on the figures of the College Portal (figs. $5 e$ \& $f$ ) owing to their serious aesthetic repercussions.

\section{Pitting, alveolar erosions and striations} logically affect the most ventilated and damp areas (figs. $6 a \& b$ ).

The pitting, alveolar erosions and striations area accompanied, especially on the College Portal, by spalling located mainly in the projecting angles and profiles (fig. 6c). Ruptures have been produced in its marble in the form of fragments and scales (fig. 6d) and abundant cracks (fig. 6e). Examples of fissures are not lacking on this façade, probably provoked by earthquakes in a city with such a high seismic activity (fig. 6f).

\subsection{Eastern Façade}

This is really oriented to the South East. This has also been constructed mainly with Santa Pudia limestone; elements with Sierra Elvira limestone also exist on the cornices. As in other façades, substitutions have been carried out in the adornments of the lower parts with a highly-polished stone whose origins are unknown. Some surfaces, such as the Lonja wall, have been plastered with Portland cement.

The sun shines on it in the morning. However, due to the proximity of houses, the area corresponding to the first level up to its crowning cornice is always shaded except a part of the wall opposite Estribos street where a high dampness 
la calle Estribos, existiendo permanentemente una gran humedad. La humedad ascendente del subsuelo alcanza hasta dos metros de altura.

La calle que corre paralela a la fachada está cerrada al tráfico rodado, por lo que los contaminantes del aire deben ser los procedentes de la Gran Vía próxima y aquellos que de manera general contaminan el ambiente urbano por calefacciones.

La gran proliferación de agentes biológicos encuentra su mejor representación en el amplio desarrollo de líquenes en todas las superficies rampantes, así como en las lavadas por el agua procedente de gárgolas; en el crecimiento de musgo en las zonas adyacentes al suelo, y en las plantas superiores que crecen en las cornisas y en las quiebras y molduras de los contrafuertes. Una parte importante de la zona de suelo adyacente a la fachada, está ajardinada, con profusión de árboles, y arbustos, contribuyendo a agravar la situación de humedad.

Todo el primer nivel de la fachada presenta un antiguo enlucido con restos de pintura de color rojo. Asimismo, existe una fuerte pátina debida al paso del tiempo, que oscurece el color natural de la piedra. Son abundantes los depósitos de polvo y de materia carbonosa (Fig. 7a), sobre todo en las zonas adyacentes a la cornisa y en los pináculos y cresterías del primer nivel. En los niveles superiores estos depósitos disminuyen aun cuando se observa una orientación preferente para los mismos. Efectivamente, en las superficies orientadas al nordeste (Gran Vía) son mayores los ennegrecimientos.

Dichos depósitos, que en las zonas húmedas adquieren una gran coherencia por el desarrollo en su seno de microorganismos, presentan frecuentes disyunciones tanto en forma de películas delgadas, en las que el material subyacente permanece inalterado, como de costras, en que el mismo aparece arenizado (Fig. 7b). Estos indicadores se presentan con mayor frecuencia y gravedad en los volúmenes más próximos a la Gran Vía.

Se observan arenizaciones asociadas a ciclos de cristalización de sales tanto en las zonas afectadas por la humedad ascendente (Fig. 7c), como en aquéllas de mayor retención de humedad (cornisas, cresterías, gárgolas, etc.) (Fig. 7d).

En las zonas más aireadas, la pérdida de materia conduce a la formación de huecos, ya en forma de picados (Fig. 7e) y alveolizaciones (Fig. 7f), o bien de estriados, a veces de tipo vermicular.

Las cresterías, incluso en sus remates minuciosamente tallados, conservan perfectamente las formas, por lo que los fenómenos de erosión y corrosión asociados al exists. The rising damp from the subsoil reaches two metres high.

The street which runs parallel to the façade is closed to circulating trafic so the contaminations in the air must come from the nearby Gran Via and from those which normally contaminate the urban environment through heating.

The great proliferation of biological agents is best represented in the extensive development of lichens on all the rampant surfaces as well those washed by water from the gargoyles; the growth of moss on the adjacent areas to the ground and the superior plants which grow on the cornices and in the cracks and mouldings of the butresses. An important part of the ground area adjacent to the façade is a garden; with a profusion of trees and bushes which aggravate the dampness situation.

All the first level shows an ancient plastering with remains of red paint. At the same time there is a strong patina due to age which obscurs the natural colour of the stone. The deposits of dust and carbonaceous material are high (fig. 7a) above all on the areas adjacent to the cornices, on the pinnacles and crests of the first level. These deposits diminish on the higher areas even when a preferent orientation is observed. The blackenings are greater on the areas facing North East (Gran Via).

Said deposits, which in damp areas acquire a great coherency owing to the development of micro-organisms within them, show frequent disjunctions in the from of thin films, in which the sujacent material is unaltered, as well as crusting, in which this appears grain disgregated (fig. $7 b$ ). These indicators are shown more frequently and seriously in the buildings nearer the Gran Via.

Grain disgregations associated with salt crystallization cycles are seen in the areas affected by rising damp (fig. 7c) as well those of greater retention of dampness (cornices, crests, gargoyles, etc) (fig. 7d).

In the more ventilated areas the loss of material leads to holes, either in form of pitting (fig. 7e) or alveolar erosions (fig. 7f) or striations, sometimes of vermicular type.

The crests, incluiding their minutely carved tips, are perfectly conserved so the phenomena of erosion and corrasion associated to wind are not seen as important indicators of deterioration. It 


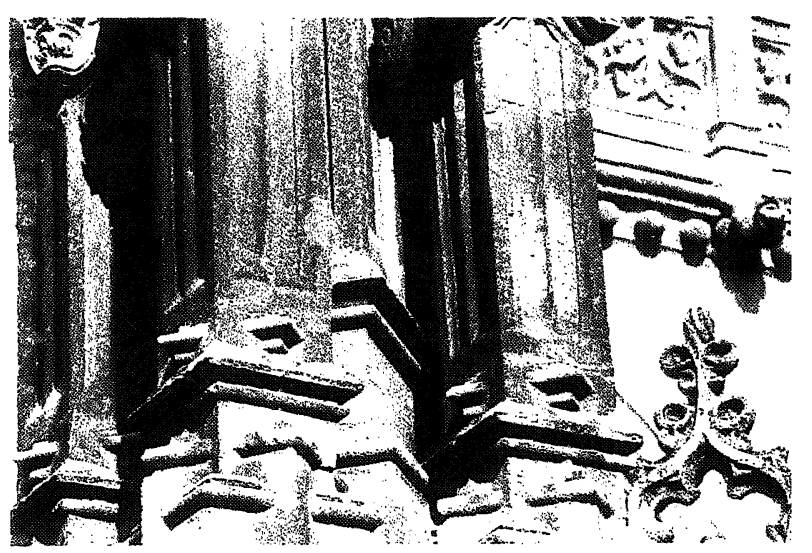

a) Depósitos de materia carbonosa.

a) Deposits of carbonaceous material.

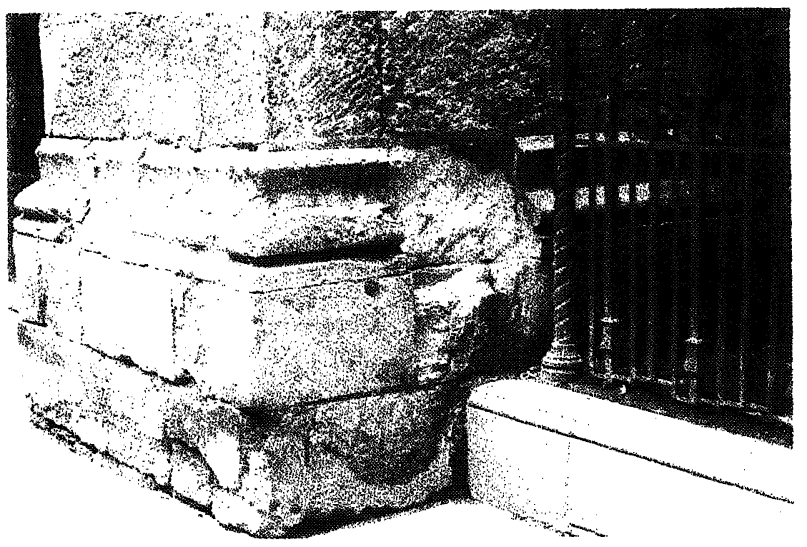

c) Arenizaciones por humedad ascendente.

c) Grain disgregations due to rising damp.

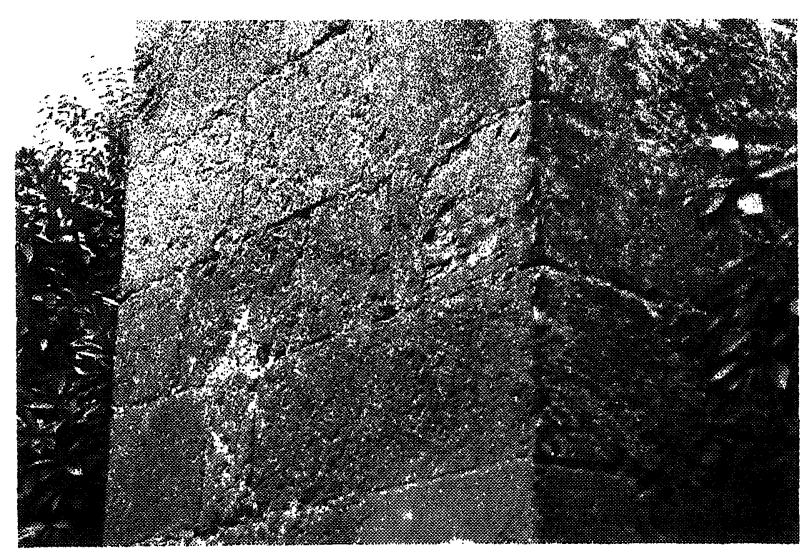

e) Picados.

e) Pitting.

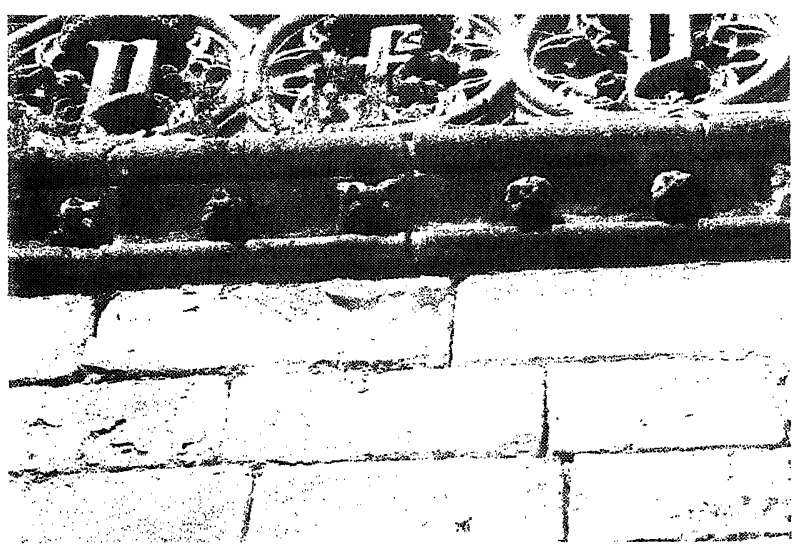

b) Disyunciones de películas y costras.

b) Film and crust disjunctions.

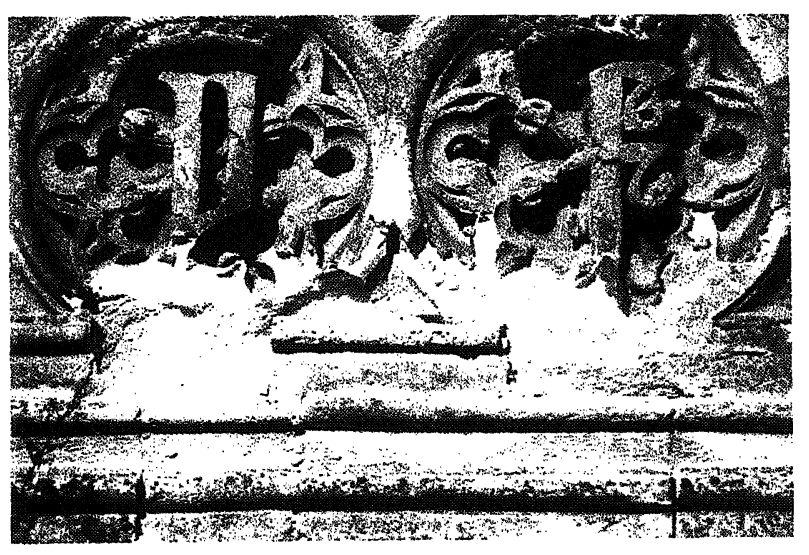

d) Arenización en creterías.

d) Grain disgregations on crestings.

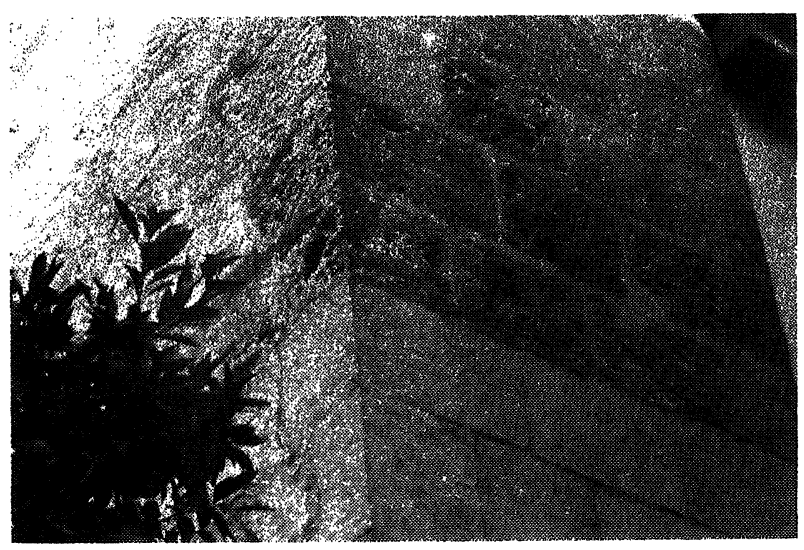

Fig. 7.-Indicadores visuales de alteración. Fachada este (Lámina 1).

Fig. 7.- -Visual indicators of deterioration. Easthern façade (llustration 1). 

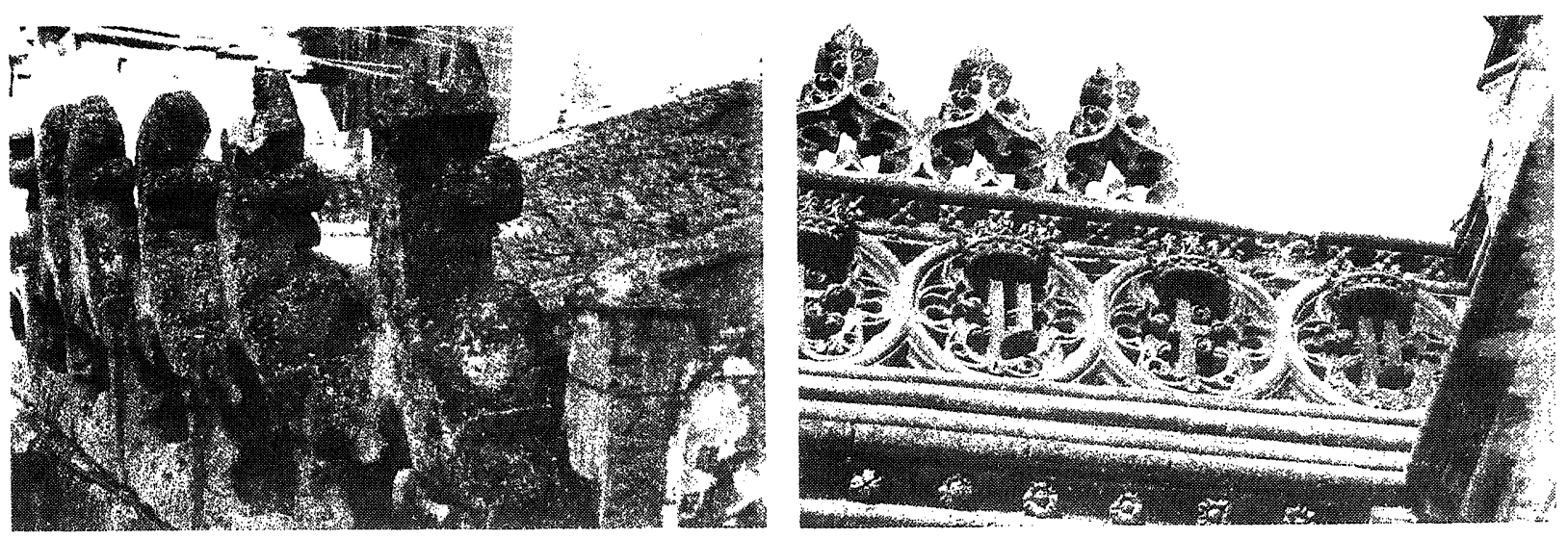

a) Fisuraciones por congelación.

b) Pérdida de elementos decorativos por rupturas.

a) Fissures due to freezing.

b) Loss of ornamental elements due to ruptures.
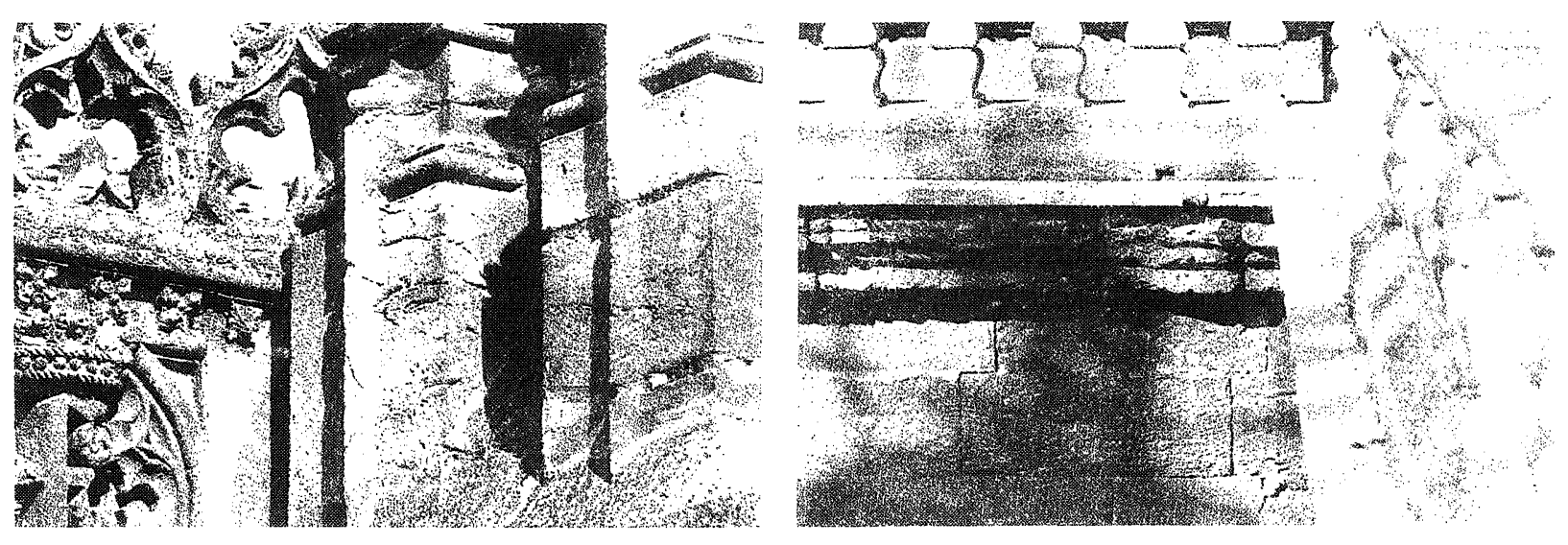

c) Fisuraciones en bases de pináculos.

d) Fracturaciones en piedras de Sierra Elvira.

c) Fissures in the pinnacles bases.

d) Cracks on the Sierra Elvira stones.
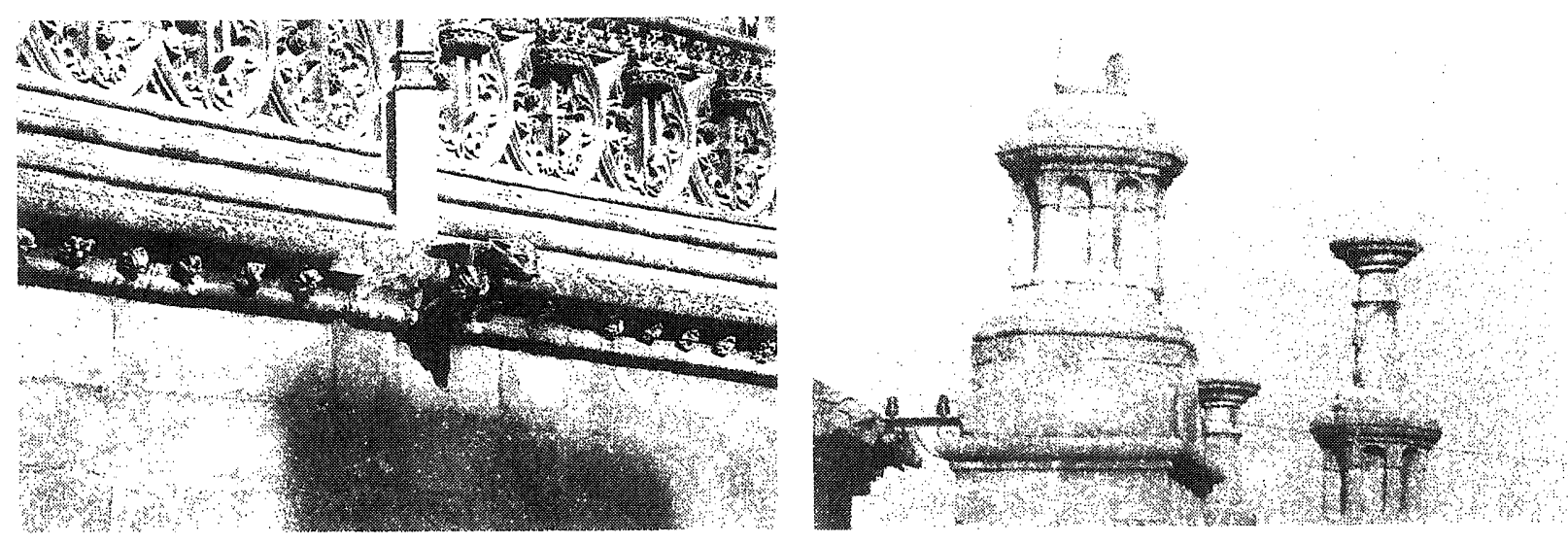
e) Fragmentaciones en cornisas.
e) Spalling on the cornises.

f) Rupturas por oxidación de espigas.

f) Ruptures due to the oxidation of iron elements.

Fig. 8. - Indicadores visuales de alteración. Fachada este (Lámina 2).

Fig. 8.---Visual indicators of deterioration. Easthern façade (Ilustration 2). 
viento no se muestran como indicadores de alteración importantes. Es muy significativo el hecho de que éstos adornos observados desde el exterior presentan un aparente buen estado de conservación, salvo por las arenizaciones anteriormente mencionadas, $y$, sin embarbo, vistos desde el interior, su superficie umbría presenta gravísimos indicadores de fracturación y fisuración (Fig. 8a), que a veces llevan a la fragmentación e incluso a la pérdida total o parcial del elemento decorativo (Fig. 8b), con posibles y peligrosos desprendimientos de trozos de material. Dichos fenómenos de alteración parecen estar asociados a mecanismos de heladicidad, favorecidos por la climatología de la ciudad. También aparecen fisuraciones en las bases de los pináculos (Fig. 8c).

Las fracturaciones en los elementos de piedra de Sierra Elvira, situados en la parte superior de las cornisas (Fig. 8d), están propiciadas por la mayor compacidad de este litotipo. En las cúpulas son muy abundantes las fisuras sobre todo en las zonas de mayor penetración de humedad, como ocurre en las cornisas, que en su base se encuentran inclinadas hacia el interior y en las molduras, generalmente, cerca de las superficies horizontales. Aun cuando, a veces, no se observan estos indicadores, el sonido "a hueco" al golpearlas revela la existencia de hinchamientos. Las cornisas se ven afectadas por abundantes pérdidas de fragmentos (Fig. 8e).

Los anclajes de hierro utilizados para la fijación de pináculos y otros elementos decorativos, debido al hinchamiento producido por oxidación, han provocado en las terrazas superiores la ruptura de la base y la consiguiente pérdida de estabilidad de dichos elementos. Por esta razón, son numerosos los casos de caída o bien de derribo intencionado por motivos de seguridad (Fig. 8f). Realmente, es preocupante la situación de ruina de bastantes pináculos.

Se observan algunas fisuraciones provocadas por terremotos, o cargas del edificio, siendo aparentemente la más importante la existente en la fachada del Sagrario. is significant that these adornments when seen from the exterior show and apparently good state of conservations, except for the afore-mentioned grain disgregations while, when seen from the interior their shady area they show very serious indicators of cracking and fissuring (fig. 8a). These sometimes lead to spalling and even total or partial loss of decorative elements (fig. 8b) with a possibly dangerous loosening of pieces of material. Said deterioration phenomena seem to be associated with freezing mechanisms favoured by the city climatology. Fissures also appear in the bases of pinnacles (fig. $8 \mathrm{c}$ ).

The cracking of stone elements from Sierra Elvira situated on the top part of the cornices (fig. 8d) are propitiated by the greater compressibility of this stone type. Fissures are very abundant on the domes, above all in the areas of greater penetration of dampness as occurs on the cornices whose bases are inclined inwardly and in the moulds, usually near the horizontal surfaces. Even though these indicators are not sometimes seen, the "hollow" sound on hitting them reveals the existence of swellings. The cornices are affected by high losses of fragments (fig. 8e).

The iron anchors used to fix the pinnacles and other decorative elements in place have provoked the rupture of the base and consequent loss in stability of said elements due to swelling caused by oxidation. That is why the cases of falls or intentional demolition due to security measures are numerous (fig. 8f). The state of ruin of quite a lot of pinnacles is really worrying.

Some fissuring caused by earthquakes or building strains can seen, the most important being the one the Sagrarium façade.

\section{BIBLIOGRAFÍA}

(1) FONT TULLOT, I. (1983) "Climatología de España y Portugal". Ed. Instituto Nacional de Meteorología, Madrid.

(2) I.N.M. (1982) "Guía resumida del Clima de España".

(3) GONZALEZ-DONOSO, J. M. (1967) "Estudio geológico de la Depresión de Granada". Tesis Doctoral, Universidad de Granada, Memoria inédita.

(4) MARTIN, L. (1992) "Diagnóstico sobre el estado de alteración de los materiales pétreos de la Catedral de Granada", Tesis Doctoral, Universidad de Sevilla.

(5) MARTIN, A. (1990) "Ensayos y experiencias de alteración en la conservación de obras de piedra de interés histórico artístico". Ed. CEURA, Madrid. 